\title{
The effect of nanoparticles on reservoir wettability alteration: a critical review
}

\author{
Hilmy Eltoum ${ }^{1} \cdot$ Yu-Long Yang ${ }^{1} \cdot$ Ji-Rui Hou ${ }^{1}$
}

Received: 2 July 2019 / Published online: 20 September 2020

(c) The Author(s) 2020

\begin{abstract}
A novel concept of treating oil reservoirs by nanofluids is being developed to improve oil recovery and reduce the trapped oil in hydrocarbon reservoirs. Nanoparticles show great potential in enhancing oil recovery under ambient conditions. In this paper, the approaches of wettability alteration by using nanofluid, stability of nanofluids, and the most reliable wettability alteration mechanisms associated with variant types of nanoparticles have been reviewed. Moreover, the parameters that have a significant influence on nanofluid flooding have been discussed. Finally, the recent studies of the effect of nanoparticles on wettability alteration have been summarised and analysed. Furthermore, this paper presents possible opportunities and challenges regarding wettability alteration using nanofluids.
\end{abstract}

Keywords Enhanced oil recovery $($ EOR) $\cdot$ Nanofluid injection $\cdot$ Wettability alteration $\cdot$ Nanoparticles $\cdot$ Contact angle

\section{Introduction}

Enhanced oil recovery (EOR) methods applied in hydrocarbon reservoirs typically cover different mechanisms, including IFT reduction, wettability alteration, mobility control, and gravity drainage. Due to the increased demands in the global energy market, oil companies are required to invent novel solutions to improving oil recovery. Nanoparticles (NPs) are considered as one of the promising chemical methods in EOR applications (Kazemzadeh et al. 2019).

Nanoparticles are defined in most references as the group of molecules bonded together to form particles with the smallest sizes ranging from 1 to $100 \mathrm{~nm}$ (Ehtesabi et al. 2017; Mahmoud et al. 2016; Torsater et al. 2012).

Edited by Yan-Hua Sun

Hilmy Eltoum and Yu-Long Yang contributed equally to this work

Hilmy Eltoum

Hilmy.eltoum@hotmail.com

Yu-Long Yang

yangyulong0206@126.com

Ji-Rui Hou

houjirui@126.com

1 Unconventional Petroleum Research Institute, China University of Petroleum-Beijing, Beijing 102249, China
Nanoparticles have beneficial characteristics in EOR application compared with other injection fluids used in conventional EOR methods such as gas, polymer, surfactant, alkali, steam, and other chemicals (Almahfood and Bai 2018; Druetta and Picchioni 2019). In addition to the ultrasmall sizes that allow nanoparticles to move through porous media without critical permeability reduction, the high ratio of its surface area to volume leads to enhancing other critical properties of nanofluids (Rahmani et al. 2015). Those distinguishing features of nanoparticles allow additional oil recovery by changing the interfacial tension between oil and water and altering reservoir rock wettability towards more water wet (Nazari Moghaddam et al. 2015).

In the oil and gas industry, various applications of nanoparticles and nanofluids are under investigation, focusing on how they influence drilling operations, production development, reduction of formation damage, enhanced/improved oil recovery, heat transfer, and treatment of wastewater (Franco et al. 2017). In EOR/IOR applications, the most frequently used nanoparticles are $\mathrm{SiO}_{2}, \mathrm{Al}_{2} \mathrm{O}_{3}, \mathrm{MgO}, \mathrm{ZrO}_{2}$, $\mathrm{CeO}_{2}, \mathrm{TiO}_{2}, \mathrm{ZnO}$, and $\mathrm{Fe}_{2} \mathrm{O}_{3}$.

Recently, nanoparticles have been investigated to solve various challenges in oil production, such as trapping and controlling fines migration (Ogolo et al. 2013; Yuan et al. 2018), viscosity reduction for heavy oil by performing as a catalyst agent (Prasher et al. 2006; Taheri-Shakib et al. 2018), increasing the viscosity of injection fluids to improve 
the displacement efficiency (Tarek 2015; Zaid et al. 2014), improving the efficiency of polymers and surfactants (Cheraghian 2015, 2017a, b; Singh and Mahto 2017), and reduction of the polymer degradation caused by temperature and shear rate effects (Giraldo et al. 2017).

Over the last several years, many types of research have been conducted on reservoir wettability alteration, whereby wettability is described as one of the main parameters that control the performance of EOR methods (Lim et al. 2015). Many researchers proved that reservoir wettability could be altered from strongly oil wet to strongly water wet by injecting nanofluids (Al-Anssari et al. 2016; Alhammadi et al. 2017; Tola et al. 2017), which was confirmed by measuring contact angles on smooth sample surfaces in the presence of nanofluids.

Among the nanotechnologies that had been investigated and applied in trial fields, the nanofluid trial has been implemented in the Cupiagua Field in Colombia (Franco et al. 2017); the study was carried out to improve the heavy and extra-heavy oil mobility based on laboratory experiments. This is consistent with by Zabala et al. (2016), where implemented nanofluid injection in trial fields was tested in regard to their ability to improve oil mobility and remove formation damage due to asphaltenes precipitate in two Colombian heavy oil fields, namely Castilla and Chichimene. The results showed that nanoparticles could alter rock wettability from oil wet to water wet, with concomitant increases in oil recovery (Zabala et al. 2016).

This paper discusses the effects of nanoparticles on wettability alteration, taking into account what has been accomplished. A thorough review of the uses, characterisations, preparations, and different mechanisms of nanofluid preparation with a focus on wettability alterations has been carried out utilising updated citations from the latest review articles. The recent developments in single and composite nanofluids are summarised in this paper. This review provides new data on existing nanoparticle applications and the possibility of wide-scale implementation in fields and can also catalyse additional investigation of nanotechnology applications in EOR.

\section{Stability of nanofluids}

Preparation of nanofluids is the first key step in experimental studies of nanofluids. Generally, nanofluids are prepared by two methods: two-step method and one-step method. In the two-step method, a nanofluid is formed by dispersing nanoparticles (NPs) into base liquids such as water, ethylene, ethanol, or oils to form a single nanofluid or by dispersing a mixture of nanoparticles (NPs) to form a nanofluid mixture (Lee et al. 2008; Mahbubul 2019a). In the one-step method, NPs are formed and dispersed in the same fluid simultaneously. Therefore, preparation of a stable nanofluid is considered a significant challenge in most recent studies and the stability of nanofluids depends on several factors such as nanofluid preparation method, NP concentration, types of additives, and base fluid nature.

Preparing a stable nanofluid requires a high quality of NPs with non-agglomeration of particles in the base liquid. More stable nanofluids enable higher oil recoveries during the flooding process. Some authors assumed that the nanofluid concentration affects the oil reservoir permeability, wherein an increase in NP concentration may lead to blocking in the porous media (Bayat and Junin 2015).

Since the stability of nanofluids plays a significant role in their performance, several researchers used various methods, techniques, and instruments to improve the stability of nanofluids. In this regard, ultra-sonication and magnetic stirring are the well-known mechanical mixing methods for dispersing NPs to form a stable nanofluid (Cheraghian 2017a, b). Ultrasonic processors are a conventional technique which is extensively used by many researchers (Asadi 2019; Shen 2019). Chung et al. (2009) prepared a suspension of $\mathrm{ZnO}$ NPs in water using an ultrasonic processor within in $60 \mathrm{~min}$ (Chung et al. 2009). Graves et al. (2019) used 30-min sonication time in ultrasonic step to break down the agglomeration of copper nanopowders in methanol. They concluded that using the ultrasonic processor in nanofluid preparation would break down the agglomeration of NPs and improve the stability of nanofluids (Graves et al. 2019). Further, Lee et al. (2008) reported that using ultrasonic vibration for five hours led to a stable $\mathrm{Al}_{2} \mathrm{O}_{3}$ nanofluid with little aggregation (Lee et al. 2008), while Mahbubul et al. (2015) concluded that the better dispersion of $\mathrm{Al}_{2} \mathrm{O}_{3}$ nanoparticle in water has been absorbed with the increases in sonication time, and 2 hours of ultra-sonication showed better performance (Mahbubul et al. 2015).

The addition of chemical additives is considered as a conventional method to improve the stability of nanofluids and to minimise particle aggregation. The commonly used additives include surfactants and $\mathrm{pH}$ control agents. Surfactants are added to decrease the surface tension of liquids and improve the suspension time of particles (Schramm 2000). Diverse types of surfactants including polyethylene oxide (PEO) (Hogeweg et al. 2018), polyvinylpyrrolidone (PVP) (Hendraningrat and Torsæter 2014a), sodium dodecyl sulphate (SDS) (Choi et al. 2018), CTAB (Choudhary et al. 2019), and sodium oleate surfactant (Llanos et al. 2018) have been employed to increase the stability of nanofluids.

Choudhary et al. (2017) experimentally investigated the stability of nanofluids. They reported that the highest values of zeta potential are on the higher sides of acidic and basic areas (Choudhary et al. 2017). Further, Ghadimi and Metselaar (2013) proved experimentally that the addition of $0.1 \mathrm{wt} \%$ of surfactant resulted in stabilised 
nanofluid for 30 days after preparation (Ghadimi and Metselaar 2013). Likewise, Adil et al. (2016) investigated the effect of three types of surfactants SDS, SDBS, and oleic acid on the stability of zinc oxide $(\mathrm{ZnO})$ nanofluid, and they reported that the most stable $\mathrm{ZnO}$ nanofluid was achieved at $0.025 \mathrm{wt} \%$ of surfactant (SDBS) and $\mathrm{pH}=2$ (Adil et al. 2016).

The stability of nanofluid is related to its electrokinetic characteristics. The $\mathrm{pH}$ value of the dispersed fluid may affect the stability of nanofluid due to extreme repulsive forces. Samal et al. (2010) proved experimentally the direct impact of $\mathrm{pH}$ on the nanofluid stability, and they reported that the stability of $\mathrm{Al}_{2} \mathrm{O}_{3}$-base water nanofluid was better at $\mathrm{pH}$ of 10.30 and 4.96 , corresponding to the zeta potential values of -27.70 and $49 \mathrm{mV}$ (Samal et al. 2010). The pH modification and adjustment is one of the effective methods to improve the zeta potential value of the nanofluids. The interaction of charged particles depends on the $\mathrm{pH}$ value of the system, whether a solution is acidic, basic, or neutral. For instance, if the particles are negatively charged (e.g. $\mathrm{SiO}_{2}$ particles), reducing the $\mathrm{pH}$ value of the solution leads to a stable nanofluid. This is due to the electrostatic adsorption of $\mathrm{SiO}_{2}$ particles by the hydronium ions, which repulses those particles (Jafari Daghlian Sofla et al. 2018).

The aggregation rate is more strongly influenced by different parameters such as type of base fluid and fluid/particle interfacial effects. NPs aggregate in bigger particles after dispersing in the base fluid, due to their tendency to reduce the surface energy and nature of the interactions (hydrophilic, hydrophobic, and amphiphilic) of particles-liquid during the collisions in the nanofluid. Moreover, dissolved ions in the base fluids have more effect on the stability of nanofluids, e.g. the multivalent ions in the brine $\left(\mathrm{Ca}^{2+}\right.$ and $\left.\mathrm{Mg}^{2+}\right)$ give an electric double layer on the surface of NPs (Jafari Daghlian Sofla et al. 2018).

Some researchers described several techniques to evaluate the stability of nanofluids such as zeta potential analysis, UV-Vis spectrophotometry, sedimentation method, transmission electron microscopy (TEM), scanning electron microscopy (SEM), and dynamic light scattering method. The zeta potential is known as the difference in potential between the nanofluid and the stationary layer of fluid in contact with the NPs. The high zeta potential $(+/-)$ describes the electric stability of the fluid, while the nanofluids with lower zeta potentials lead to a quicker deposition of NPs (Mahbubul 2019a). Whereas the sedimentation method is usually used to evaluate the stability of nanofluids over time, the non-appearance of any precipitates over time means the nanofluid is stable. UV-Vis spectroscopy is used to estimate the concentration of NPs in the nanofluid; TEM and SEM are used to measure the size, shape, and distribution of NPs.

\section{The mechanisms of wettability alteration by nanofluid flooding}

Nanoparticles have a different trend in a variety of EOR processes that can make significant contributions to oil recovery. Based on previous investigations, NP applications are summarised into three major approaches: (1) nanofluids which are made by adding various NPs to base liquids such as water, oil, and gas and applied to enhance water flooding recovery; (2) nano-emulsions in which NPs are used to stabilise the emulsion with droplet size in the nanometric scale; and (3) nano-catalysts which can use the NPs as catalysts for improving the efficiency of oil recovery by a continuous steam injection process in heavy oil reservoirs (Cardona et al. 2018; El-Diasty and Ragab 2013).

Overall, this discussion focuses on the nanofluid approach mentioned above, which are considered as crucial for the optimisation of EOR. The movement behaviour of nanoparticles in porous media has been investigated widely, focusing on the flow, rheological behaviour and adsorption of the nanoparticles on rocks. Oil displacement mechanisms by new nanoparticles are still not explained enough and need more investigation (Agi et al. 2018); however, the EOR mechanisms of nanofluids are summarised as follows: disjoining pressure, pore channel plugging, increasing the viscosity of injection fluids, IFT reduction, wettability alteration, and preventing asphaltene precipitation (Jiang et al. 2017; Ortega et al. 2016; Tarek 2015). Figure 1 presents a schematic of the most common nanofluid EOR mechanisms.

\subsection{Disjoining pressure}

Disjoining pressure is defined as the pressure required for removing fluids which are in contact with the reservoir rocks due to the adhesion force of fluids/solid surface (Jiang et al. 2017). Theoretical and experimental investigations show that the nanofluids reduce oil adsorption on a rock surface by entering a structural disjoining force (film) between the oil and the rock surface and then creating a wedge film structure on the rock surface. In other words, higher repulsion forces exist with smaller nanoparticles (Kopanichuk et al. 2017; Lim and Wasan 2017). In this process, nanoparticles tend to rearrange in the nanofluid, which leads to an increase in the entropy of the nanofluids; this trend is due to the considerable freedom of the NPs in the nanofluids. The result of this process exerts an additional disjoining pressure at that interface more so than in 


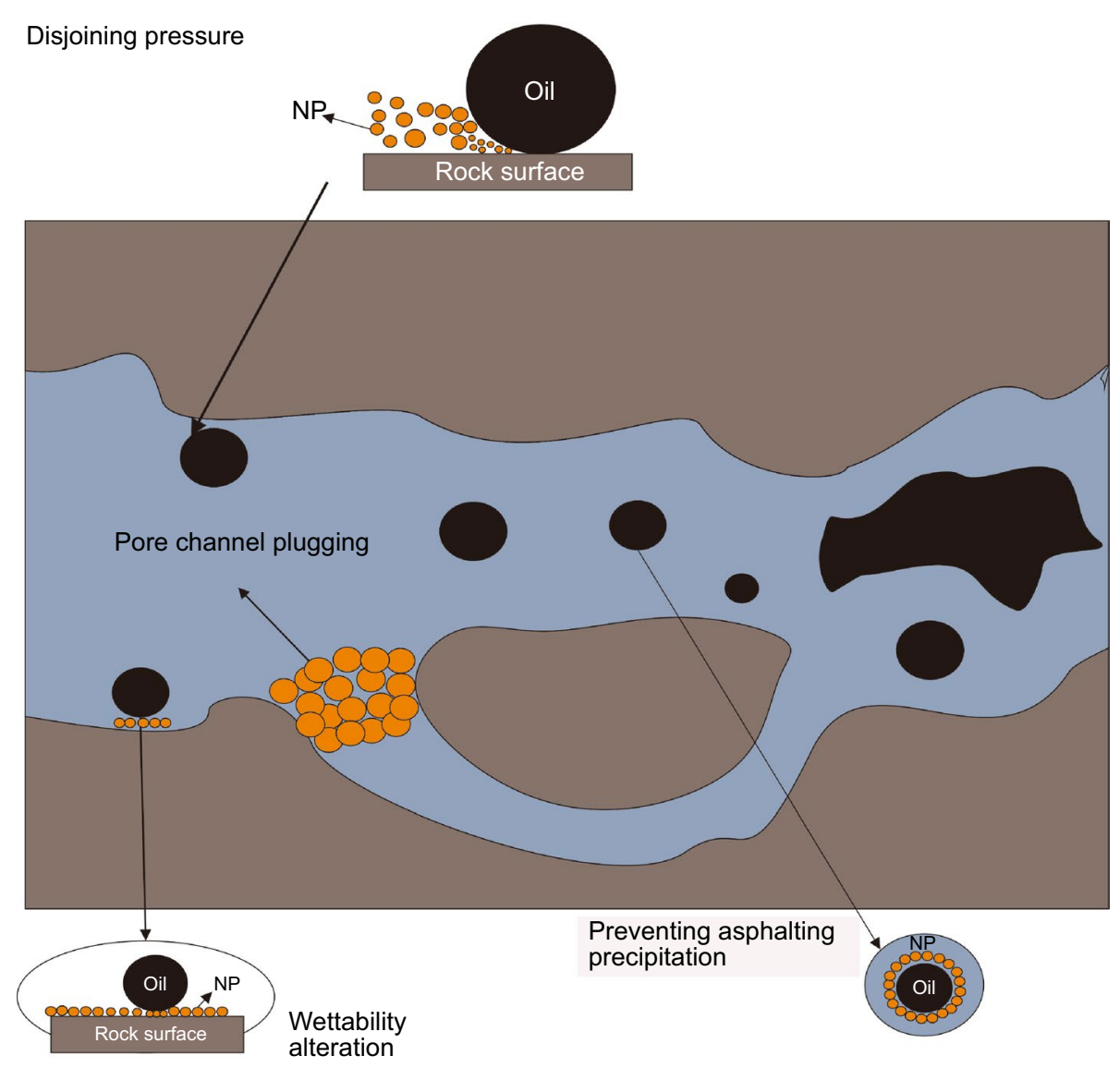

Fig. 1 EOR mechanisms of nanofluids in porous media

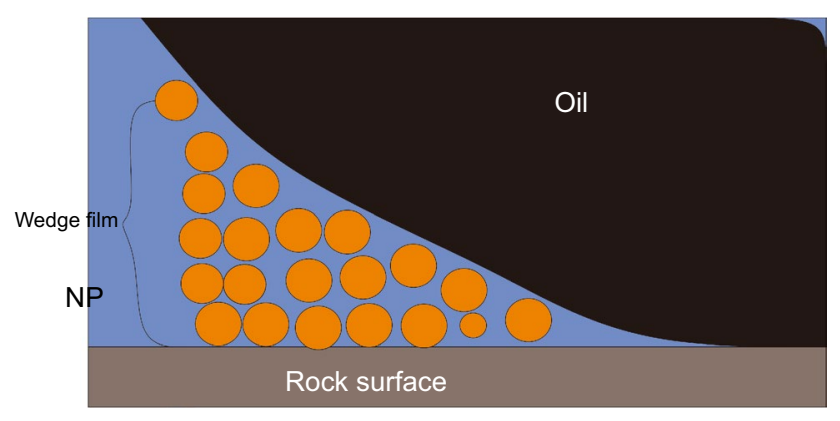

Fig. 2 Mechanisms of disjoining pressure in porous media

the bulk liquid (Fig. 2). From the literature and previous works, the most famous nano-oxides used this mechanism are $\mathrm{SiO}_{2}$ and $\mathrm{TiO}_{2}$ (El-Diasty and Ragab 2013).

\subsection{Wettability alteration method}

Generally, wettability is a significant factor influencing fluid displacement efficiency in porous media and consequently increases oil recovery. Modifying rock wettability from strongly oil wet to water wet is the most efficient method for EOR applications. Wettability can be expressed as the tendency of a fluid to spread on or adhere to a solid surface in the availability of other immiscible liquids (Bera et al. 2015). The contact angle (CA) refers to wettability alteration in the three-phase system, which can be described as the force balance between the spreading coefficient of water on a solid surface in contact with both oil and water (Aminian and ZareNezhad 2019). In laboratory experiments, different techniques are used to determine wettability, including CA measurement, Amott test, and core displacement (Agi et al. 2018).

Further, nanoparticles modify the wettability of the rock by replacing the carboxylic particles in the rock surface, creating a wedge film that displaces the oil droplets out of the rock surface by disjoining pressure (Fig. 3). In this regard, many researchers have pointed out that nanofluid can modify the wettability of rock surface (Dehghan Monfared et al. 2016). Nanoparticles are adsorbed on the rock surface and form nanotextured surfaces, which changes the rock morphology and makes it semi-homogeneous (Al-Anssari et al. 2017). Hence, a layer of nanofluids is formed on the rock surface, acting to separate and release the oil drops from the rocks and then resulting in more oil production (Kopanichuk 


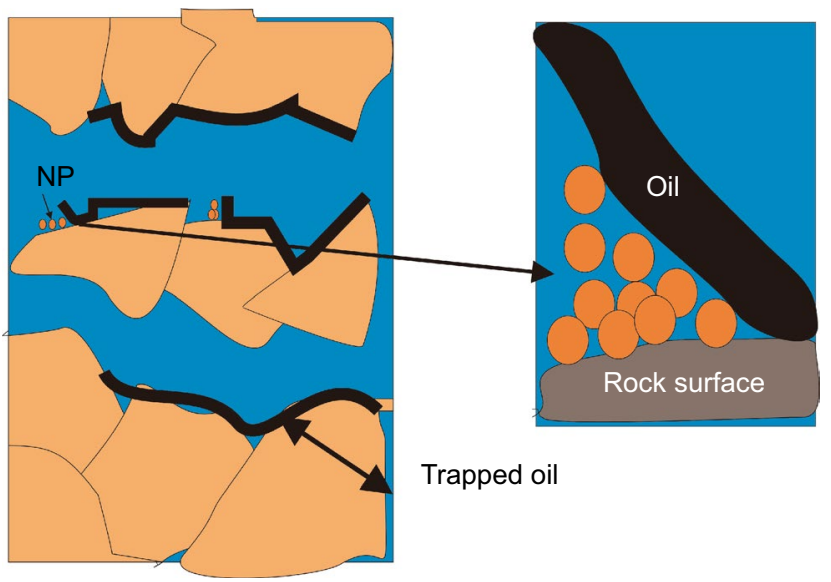

Fig. 3 Schematic of wettability alteration mechanisms of nanofluids

et al. 2017). On the other hand, the nanofluid layer could be influenced by such factors as nanoparticle concentration, size, salinity, temperature, and rock characteristics (Binks and Tyowua 2016). Also, the nanoparticles could change the monovalent and divalent $\left(\mathrm{Na}^{+}, \mathrm{K}^{+}, \mathrm{Ca}^{2+}\right.$, and $\left.\mathrm{Mg}^{2+}\right)$ in their interactions with the rock surface and result in altering the surface wettability towards stronger water wet (Jafari Daghlian Sofla et al. 2018), as shown in Fig. 4. The most widely used nanoparticles in this mechanism are silicon oxide $\left(\mathrm{SiO}_{2}\right)$ nanoparticles and titanium oxide $\left(\mathrm{TiO}_{2}\right)$ nanoparticles with most researchers concluding that the disjoining pressure is an essential mechanism in wettability alteration studies for enhanced oil recovery (Ehtesabi et al. 2017; Hendraningrat et al. 2013; Lim and Wasan 2017).

\subsection{Capillary force mechanism}

The capillary force has a significant impact on oil recovery efficiency based on the nature of the reservoirs (fractured or non-fractured). In the case of a non-fractured reservoir, the strong capillary forces cause a high percentage of trapped oil in the reservoir rock during the water flooding, while in a fractured reservoir, spontaneous imbibition of water is the critical mechanism for high oil displacement efficiency due to strong capillary forces. Hence, nanoparticles can play a vital role in recovering more trapped oil by a decrease in the capillary force (Cheraghian and Hendraningrat 2016a, b). Capillary forces are overcome by either viscous or gravitational forces; the capillary number $\left(N_{\mathrm{c}}\right)$ and bond number $\left(N_{\mathrm{b}}\right)$ are used to compare these forces. The capillary number $\left(N_{\mathrm{c}}\right)$ is determined by the ratio of viscous to capillary forces and is defined as:

$N_{\mathrm{c}}=\frac{\text { Viscous forces }}{\text { Capillary forces }}=\frac{v \mu_{\mathrm{w}}}{\sigma_{\mathrm{ow}} \cos \theta}$

where $v$ is the brine velocity; $\mu_{\mathrm{w}}$ is the brine viscosity; $\sigma_{\text {ow }}$ is the oil/water IFT; and $\theta$ is the contact angle between the rock and the wetting phase.

Nanoparticles obtained respectful consideration in the oil and gas industry due to their ability to improve physical properties for the reservoir fluids and injected fluids. Diverse research methodologies have shown the ability of nanoparticles to reduce the interfacial tension between crude oil and nanofluids through applying different nanoparticles with the size of $5 \mathrm{~nm}$. They concluded that the interfacial tension had been reduced by using nanoparticles (such as $\mathrm{Fe}_{2} \mathrm{O}_{3}$ ), which gave about a $40 \%$ reduction in the interfacial tension and resulted in a high capillary number (Gomaa et al. 2018; Rezk and Allam 2019).

\section{Factors influencing the process of flooding with nanoparticles}

Various parameters have demonstrated significant effects on the performance of single and combined nanoparticles in nanofluid flooding.

\subsection{Nanoparticle concentration}

Nanofluid concentration is one of the crucial factors in applications of nanofluid flooding, where nanoparticles
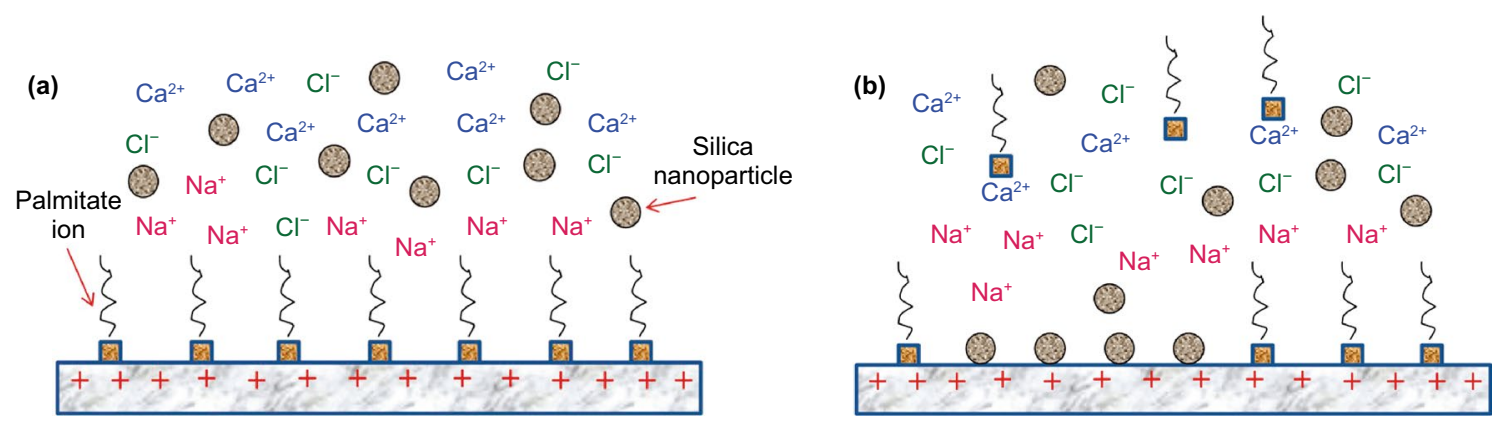

Fig. 4 Mechanism of wettability alteration of oil wet carbonate surface rock by silica nanofluid (Hou et al. 2019) 
become more efficient with increased concentration. In some investigations, the researchers focused on determining the nanoparticle concentration ranges in addition to their effect on wettability alteration. The impact of nanoparticles on wettability alteration has been studied in a wide range of concentrations; the outcome of the most studies was that the rock wettability enhancement increases with an increase in nanoparticle concentration due to the impact of repulsion forces (Bhuiyan et al. 2015).

Huminic et al. (2015) explained the effect of nanoparticle concentration on thermal conductivity, and they stated that the interaction between molecules increases with an increase in particle concentration, resulting in enhanced thermal conductivity (Huminic et al. 2015). Besides, higher concentrations of nanoparticles lead to the appearance of some suspensions, which minimised the stability of the nanofluids, and lower concentrations make it unappealing as an EOR agent (Sezer et al. 2019). Further, Masoud Hosseini et al. (2016) investigated the effect of nanoparticle concentration on the rheological behaviour of liquid paraffin, and their results demonstrated that the viscosity of the nanofluids increased with an increase in nanoparticle concentration (Masoud Hosseini et al. 2016). This is consistent with the observation of Hojjat et al. (2011) that the relative viscosity of $\mathrm{Al}_{2} \mathrm{O}_{3}$ and $\mathrm{TiO}_{2}$ nanofluids increases with increasing nanoparticle concentration (Hojjat et al. 2011).

Higher concentration of nanoparticles is expected to be more active in altering wettability, trending towards greater water wet by reducing the contact angles faster. Furthermore, adding small quantities of chemical additives is beneficial and economically visible in the oil industry; however, higher concentration of nanoparticles (more than $3 \mathrm{wt} \%$ ) may lead to a reduction in reservoir permeability (Bhuiyan et al. 2015; Sun et al. 2017). Likewise, increased concentration of nanoparticles has a strong effect on wettability alteration on the oil wet carbonate samples (Al-Anssari et al. 2016). The contact angle values were $120^{\circ}, 60^{\circ}$, and $45^{\circ}$, when the nanoparticle concentrations were $0 \%, 1 \%$, and $2 \%$, respectively, and above a nanoparticle concentration of $2 \%$, there was no change in contact angle. This suggests that any increase in nanoparticle concentration leads to an alteration of the wetting surface from oil wet to strong water wet (above $2 \%$ no change observed). Hence, Hendraningrat and Torsæter (2014a) reported that the contact angle decreased as the nanoparticle concentration increased from 0 to 0.1 wt\% (Hendraningrat and Torsæter 2014a).

Further, the nanofluid density is proportional to the volume ratio of nanoparticles to the base fluid in the nanofluid. The nanofluid density is higher than that of the water or the base fluid, and its value increases as the nanoparticle concentration increases in the base fluid (Devendiran and Amirtham 2016). Also, there is a linear correlation between the nanofluid density and the concentration of nanoparticles, mainly at ambient temperature (Sommers and Yerkes 2010), although the potential of nanoparticles to control fines migration in the sand sample $\left(\mathrm{Al}_{2} \mathrm{O}_{3}, \mathrm{SiO}_{2}\right.$, and $\left.\mathrm{MgO}\right)$ increases with nanofluid concentration (Mansouri et al. 2019).

\subsection{Nanoparticle size}

The size of nanoparticles has a direct effect on wettability alteration and is considered one of the several essential factors in the application of nanoparticles in EOR. This importance stems from the adoption of a wettability alteration mechanism such as disjoining pressure or log-jamming as a function of the application of various sized nanoparticles in the nanofluids.

In very small throats of rock pores, nanoparticles are stacked at the entrance of those throats owing to their large particle size compared with a pore channel entrance, leading to channel plugging. This process is defined as mechanical trapping (Fig. 5a). The log-jamming mechanism illustrated in Fig. $5 b$ has been interpreted as a result of the differences between particle and solvent densities. Due to the smaller size of pore throats and the continuous differential pressure, the flow velocity increases in pore throats compared to that in pore bodies. At the inlet of the pore throat, water particles flow more quickly than nanoparticles, which leads to an aggregation of particles at the pore throat entrance and creates a barrier. This accumulation of nanoparticles causes
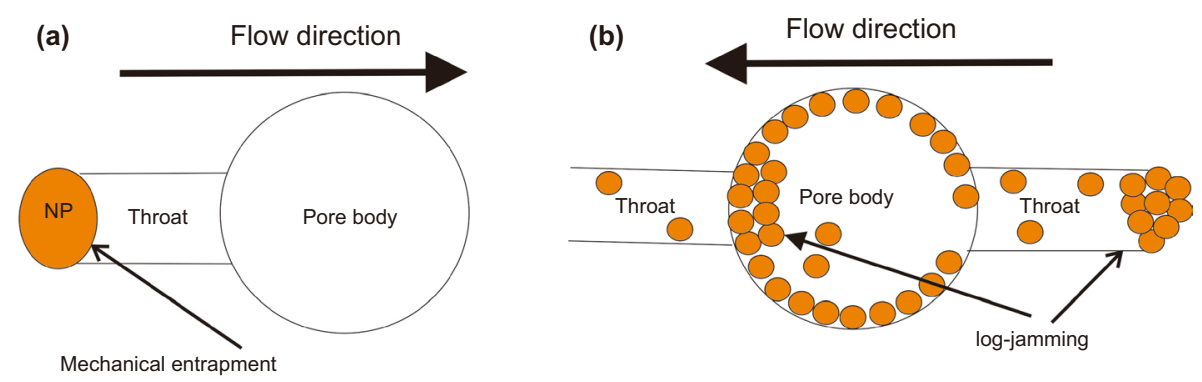

Fig. 5 The mechanisms causing pore channel plugging: a mechanical trapping and $\mathbf{b}$ log-jamming mechanism 
an eventual blockage in the throat of the pores. Finally, this will divert the water and nanofluid flooding to flow through a channel filled with trapped oil, altering the wettability through disjoining pressure mechanism and then enhancing oil recovery (Fig. 6) (Bolandtaba and Skauge 2011; Manzari Tavakoli et al. 2018).

The contact angle (CA) is considered as an indicator of wettability alteration. Contact angle values are measured before and after the samples are modified with nanofluids to indicate that the change is due to nanoparticles rather than the base fluid. Al-Anssari et al. (2017) studied the impact of particle size on the wettability alteration of calcite samples by using $\mathrm{SiO}_{2}$ nanoparticles in various sizes ( 5 and $25 \mathrm{~nm}$ ) at the same concentration (Al-Anssari et al. 2017). Their results show that $\mathrm{SiO}_{2}$ nanoparticles could effectively alter the calcite wettability, but the particles size (5 and $25 \mathrm{~nm}$ ) did not influence the wettability alteration efficiency in oil wet calcite samples. These results are consistent with the outcomes obtained by other researchers (Costa et al. 2006; Kulak et al. 2004).

Jang et al. observed that the rock wettability of limestone and dolomite was efficiently altered towards neutral wet and water wet from strongly oil wet, respectively, by surfactantmodified $\mathrm{SiO}_{2}$ nanofluids with small particle sizes $(20 \mathrm{~nm})$ (Jang et al. 2018).

Furthermore, Kwek et al. (2010) found that using smallersized $\mathrm{Al}_{2} \mathrm{O}_{3}$ nanoparticles leads to an increase in the viscosity of nanofluids but a decrease (from $30 \%$ to $10 \%$ ) in the thermal conductivity enhancement when the particle size increases from 10 to $35 \mathrm{~nm}$, and then the thermal conductivity enhancement increases when the particle size is larger than $35 \mathrm{~nm}$ (Kwek et al. 2010).

Likewise, the impact of $\mathrm{Al}_{2} \mathrm{O}_{3}$ particle sizes on the viscosity of nanofluids has also investigated elsewhere (He et al. 2007; Nguyen et al. 2007). The $\mathrm{Al}_{2} \mathrm{O}_{3}$ nanofluids had approximately the same viscosity at the nanoparticle concentration level of $4 \%$ and particle sizes of 36 and $47 \mathrm{~nm}$. He et al. (2007) and Nguyen et al. (2007) concluded that the

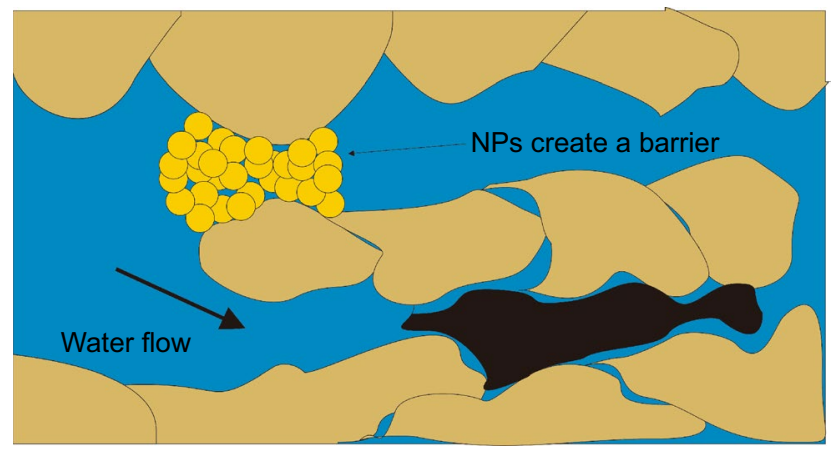

Fig. 6 Nanoparticles create a barrier, diverting water and second NPs slug to flow through a channel filled with trapped oil nanofluids with bigger size of nanoparticles show higher viscosity than that with the smaller ones when the nanofluid concentration increases (He et al. 2007; Nguyen et al. 2007). Also, Betancur et al. (2016) assessed the influence of the size of synthesised silica gel nanoparticles on the inhibition of formation damage induced by asphaltene deposition, and the results showed that the smallest nanoparticles $(11 \mathrm{~nm})$ had the highest adsorptive ability for $n$ - $\mathrm{C}_{7}$ asphaltenes among the nanoparticles investigated (Betancur et al. 2016).

\subsection{Temperature}

Working at high temperatures is considered a challenge in most chemical methods, including nanofluids. This crossstudy review found that all nanofluid researchers recognise temperature as the most significant and substantial parameter and have found a consistent, prevalent downward trend in the viscosity of nanofluids as a function of an increase in temperature (Belhaj et al. 2019). In other words, the stability of nanoparticles decreases with an increase in temperature; therefore, the performance of nanofluids in high temperature reservoirs needs to be improved, especially on wettability alteration.

Hamouda and Rezaei Gomari (2006) explained that the reduction of calcite surface positive charges was due to the increase in temperature, and this reduction may improve the repulsive forces between naphthenic acids and calcite rock. Therefore, the adsorption of naphthenic acids on the rock surface becomes less efficient at high temperatures due to the rock surface changing; and then the wettability of the calcite surface tends to be water wet (Hamouda and Rezaei Gomari 2006).

Extensive research shows that temperature has a direct effect on nanofluid proprieties such as viscosity, surface interaction among nanoparticles, and the stability of the nanofluid itself (Baratpour et al. 2016; Li et al. 2019; Wang et al. 2018). The behaviour of nanofluids (Newtonian/shear-thinning) depends on the properties of the base fluids, and their behaviour is correlated with temperature, where dispersing nanoparticles in a Newtonian base fluid would yield a nanofluid with the Newtonian behaviour, and non-Newtonian behaviour if the base fluid is non-Newtonian (Mahbubul 2019b). Some researchers thought that in the case of shear-thinning behaviour of nanofluids, nanoparticle agglomeration clusters broke down when the shear rate increased, which leads to a decrease in nanofluid viscosity (Prasher et al. 2006; Yu et al. 2017; Zawrah et al. 2016). With an increase in temperature, the nanoparticles agglomerated, which leads to a decrease in viscosity and in the zeta potential value ( $\mathrm{Li}$ et al. 2009; Schmidt et al. 2008; Turgut et al. 2009).

The impact of temperature on nanofluid viscosity has been extensively studied (Choon Pak and Cho 1998; Hojjat 
et al. 2011); the results found that the nanofluid viscosity is a function of temperature and the viscosity decreases with an increase in temperature. Gupta and Mohanty (2010) reported that temperature has a significant effect on wettability modification of solid surfaces. Specifically, they examined the effects of temperature on the contact angle measurement using nanofluid flooding. Their results demonstrated that the contact angles were reduced from $145^{\circ}$ to $38^{\circ}$ at $50{ }^{\circ} \mathrm{C}$ and changed from $145^{\circ}$ to $56^{\circ}$ when the temperature increased from 23 to $60{ }^{\circ} \mathrm{C}$. Al-Anssari et al. $(2016,2017)$ concluded that nanofluids are highly efficient on wettability alteration, particularly at higher temperatures (Al-Anssari et al. 2016, 2017). Consistent with Buonomo et al. (2015), they found that nanofluid composites can be used to best advantage at low concentrations $(>0.2 \%)$ and high temperatures $\left(>50^{\circ} \mathrm{C}\right.$ ) (Buonomo et al. 2015).

\subsection{Salinity}

Among different EOR methods, low-salinity water (LSW) flooding has attracted considerable attention due to the availability of natural water resources and also being environmentally friendly (Sheng 2014). Currently, researchers have observed that injecting low-salinity water (LSW) produced a persistent wettability alteration of the rock (towards water wet), facilitating additional oil recovery (Rivet et al. 2010). Nanofluids have an inverse relationship with salinity, where the nanofluids become less stable when salinity increases accordingly, which in turn is an indicator of the occurrence of the agglomeration of particles in the fluid.

Mansouri et al. (2019) reported the effect of nanofluid on fines migration in low-salinity water. The results showed that the $\mathrm{SiO}_{2}$ nanofluid could reduce the production of fines when mixed with low-salinity water. In other literature, experiments on wettability alteration and incremental oil recovery were conducted to understand the performance of nanoparticles mixed with low-salinity water. Different concentrations of nanofluids were prepared $(0.1,0.25,0.5$, and $0.75 \mathrm{wt} \%$ ) by dispersing $\mathrm{SiO}_{2}$ nanoparticles in low-salinity water obtained from Persian Gulf seawater (Dehaghani and Daneshfar 2019). A conclusion was drawn that nanoparticles could enhance the ability of low-salinity water to alter wettability and improve sweep efficiency. However, the wettability alteration occurs when the temperature reaches only up to $80{ }^{\circ} \mathrm{C}$ and ascribes to higher activities of dissolved ions at a high temperature. Many authors summarised that saline water could improve rock wetting and enhance the effectiveness of nanoparticles to improve incremental oil extraction (Mohammad Salehi et al. 2017; Zekri et al. 2015).

The effect of salinity on wettability alteration of the rock ascribes to an interaction between the potential ions such as $\mathrm{Ca}^{2+}, \mathrm{Mg}^{2+}$, and $\mathrm{SO}_{4}^{2-}$ and the adsorbed carboxylic material on the rock surface (Gandomkar and Rahimpour 2017), whereby an ionic interaction among oppositely charged (positive/negative) sites at rock/water interface (attractive, repulsive, or both) could lead to wettability alteration (Alshakhs and Kovscek 2016). Some researchers observed that the use of saline water (seawater) caused a reduction in the contact angle, and they pointed out that a change in the contact angle was tangible notably after switching from formation water to high-salinity water (Mahani et al. 2015).

Regarding salinity impacts on wettability alteration, several researchers observed that the positive ions interact with negative ions on the rock surface that modify rock wettability to water wet. The nature of the rock surface is an essential factor in the wettability alteration mechanism. As identified by Al-Hashim et al. (2018) the positively charged ions on the dolomite surfaces act as an attraction for negative charge end components in polar crude oil; they observed strong interaction between ions in the presence of high-salinity water. Whereas calcite surfaces showed a relatively fixed trend with the application of different salt concentrations (Lashkarbolooki et al. 2016), higher oil recovery rates were attributed to the concentration of those ions in the rocks layers (Puntervold 2008), and this, in turn, resulted in improved rock wettability alteration in low-salinity water towards strongly water wet and enhanced oil recovery (Nicolini et al. 2017), whereas Jafari Daghlian Sofla et al. (2018) confirmed that the presence of multivalent ions in the base fluid destabilises nanoparticles $\left(\mathrm{SiO}_{2}\right)$ and affects their efficiency to change the rock wettability towards water wet (Jafari Daghlian Sofla et al. 2018).

\subsection{Reservoir permeability}

Generally, reservoir permeability reduction is considered as one of the essential limitations of EOR applications in reservoir engineering, especially in chemical methods (polymer flooding). The reservoir permeability could be affected by formation damages (Aksu et al. 2015).

Clay swelling is considered as one of the factors that could reduce reservoir permeability, and thus, the effects of nanoparticles on clay swelling and migration have been examined. The experiments gave a clear indication that nanoparticles had no significant influence on the inhibition of clay swelling or formation damage caused by clay swelling; instead, the injection of high-concentration nanofluids leads to a reduction in the permeability of the porous media (Sameni et al. 2015). Hence, avoiding the agglomeration of the nanoparticles in low- and medium-permeability reservoirs $(>50 \mathrm{mD})$ is considered as one of the nanoparticle application challenges.

Nanofluids have the potential to work in both low- and high-permeability environments (Hogeweg et al. 2018; Kazemzadeh et al. 2018). Yuan et al. (2017) investigated the effects of nanofluids on permeability reduction by injecting 
nanofluids into oil wet Berea sandstones, and they monitored the changes in pressure over the experimental period. The results suggested that the permeability reduction increased as a function of elevated nanoparticle concentration (Yuan et al. 2017), notably $\mathrm{MgO}$ and $\mathrm{ZnO}$ nanoparticles (Ogolo et al. 2012).

\subsection{Injection rate of the nanofluid}

Nanofluid is commonly prepared by dispersing nanoparticles into the base fluid; deionised water is one of the most common base fluids used in the nanofluid preparation. In the porous media, the water molecules move faster than the nanoparticles because of the smaller size of water molecules compared with nanoparticles. During nanofluid injection, the use of a high injection rate leads to a conglomerate of nanoparticles in the form of large particles that cause blockage of pores and decrease the incremental oil recovery. $\mathrm{Li}$ et al. (2017) used a micromodel to investigate the effect of silica nanofluids on wettability alteration; they reported that the oil recovery decreased from $50 \%$ to $43 \%$ when the injection rate of deionised water, and residual oil saturation decreases from $24 \%$ to $20 \%$ in the case of the nanofluid injection, as the flow rate varies in the same range from 0.5 to $5.0 \mu \mathrm{L} / \mathrm{min}$ ( $\mathrm{Li}$ et al. 2017).

\section{Review on using nanoparticles and its effect on wettability alteration}

Wettability alteration is an essential mechanism in oil recovery applications. Therefore, recently nanoparticles have played a vital role in increasing oil production by changing the wetting system from oil wet to a strongly water wet. It is well known that there are some active agents and techniques which can be applied to alter the wettability of rock surface (Cheraghian 2016; Moncayo-Riascos et al. 2017; RezaeiDoust et al. 2009), but the economic and environmental factors should be considered. Recently, many researchers recognised that nanoparticles had a clear impact on the wettability alteration and would increase the rate of oil production. It is crucial to take into account the concept of disjoining pressure during nanofluid flooding to understand the mechanism of wettability alteration of the reservoir from oil wet to water wet.

As the application of nanoparticles is growing in the oil industry, various experimental studies have proved that the application of nanoparticles is capable of modifying the reservoir wetting characteristic towards a water wet, and this prompted researchers to continue experimentally investigate the effects of different nanoparticles on wettability alteration. Practically, wettability conditions are evaluated before and after surface alteration with different additives by measuring the contact angle in the presence of displacing fluid. The effect of nanofluids on reducing the surface forces has been extensively studied recently (Almahfood and Bai 2018; Jiang et al. 2017; Manoudis and Karapanagiotis 2014).

Recently, many authors investigated the application and mechanism of nanoparticles in wettability alteration for enhanced oil recovery, as mentioned in Sect. 3. Some of them assume that nanoparticles interact with other additives such as a surfactant or polymer, resulting in an improvement in their capability to alter the wettability of rock to stronger water wet and enhance oil recovery (Lim et al. 2015; Wang et al. 2019; Yin et al. 2019).

Furthermore, Tola et al. (2017) studied empirically in their research the effect of adding zinc oxide ( $\mathrm{ZnO})$ NPs on the wettability alteration in the sandstone rock. They concluded that the nanofluid $(\mathrm{ZnO})$ is useful in wettability alteration of sandstone rocks from strongly oil wet to water wet resulting from the adsorption of NPs on the sandstone rock surface (Tola et al. 2017). Also, injecting the alumina $\left(\mathrm{Al}_{2} \mathrm{O}_{3}\right)$ nanofluid into the sandstone reservoir leads to wettability alteration towards water wet by enhancing the performance of the surfactants with the low concentration of 100 ppm NP (Giraldo et al. 2013).

Moreover, the ability of nanoparticles to enhance oil recovery with different wettability conditions has been investigated. For instance, $\mathrm{ZrO}_{2}$ nanofluid has stable performance in altering the wettability on the quartz surface to strongly water wet and improved the oil recovery better than conventional chemical methods (Jha et al. 2019).

On the other hand, the application of nanoparticles on gas wetting has been investigated. Franco-Aguirre (2018) conducted contact angle measurements and imbibition experiments to investigate the influence of nanoparticles on removing condensate blockage in gas condensate reservoirs. An anionic-functionalized $\mathrm{SiO}_{2}$ nanofluid altered the system wettability from strongly liquid wet to gas wet (FrancoAguirre et al. 2018). But, Ahmadi et al. (2019) evaluated the performance of natural $\mathrm{CaCO}_{3}$ (Bio-Ca) nanoparticles containing chitin for wettability alteration and contact angle of condensate droplet raised from $0^{\circ}$ to $105^{\circ}$ after the rock surface was treated by $0.05 \mathrm{wt} \%$ Bio-Ca.

Moreover, Moncayo-Riascos et al. (2019) studied the behaviour of wettability alteration from liquid wet to gas wet by $\mathrm{SiO}_{2}$ nanoparticles functionalized with fluorocarbon surfactant Silnyl FSJ (SY). They proved that the SYfunctionalized $\mathrm{SiO}_{2}$ nanofluid can alter the wettability of the sandstone rock from oil wet to gas wet (Moncayo-Riascos et al. 2019).

Furthermore, using nanoparticles combined with polymer or surfactant is a promising method in EOR, Yousefvand and Jafari (2018) studied the effect of polymeric silica nanofluid on the oil recovery in a strongly oil wet system and reported that the oil recovery was considerably enhanced 
by changing the rock wettability towards water wet (Yousefvand and Jafari 2018), which is consistent with the experimental results obtained by Gbadamosi et al. (Gbadamosi et al. 2019). Recently, using smart nanosheet materials in the field of EOR caught more attention due to their efficiency in reducing IFT and wettability alteration. Raj et al. (2019) used 2D smart nanosheet with a concentration of $0.005 \%$ in brine salinity of $98,171 \mathrm{mg} / \mathrm{L}$ for EOR and proved the promising of $2 \mathrm{D}$ nanosheet in wettability alteration, which changed the wetting system from oil wet to strongly water wet and increased the oil recovery to $21.18 \%$ and $18.25 \%$ during tertiary flooding in $25 \mathrm{mD}$ (Raj et al. 2019). Also, Luo et al. (2016) used graphene as nanosheet with a concentration of $0.005 \%-0.01 \%$, and the recovery oil was about $15.2 \%$ through altering the wettability of the rock surface (Luo et al. 2016). The wettability alteration towards water wet condition is favoured for enhancing oil production. Table 1 summarises the experimental investigations that discuss the wettability alteration of nanoparticle floodings.

\section{Challenges and opportunities for future research}

Engineers and scientists have to discuss and overcome several issues and challenges in terms of nanofluid stability and wettability alteration by NPs for more efficient implementation in the oil and gas industry.

Preparation and stability of nanofluids face various challenges, technically and economically. The main methodological difficulty is in preparing a homogeneous fluid of nanoparticles and stable for a long time, because the particles regularly tend to aggregate due to the strong interactions between particles. Likewise, the stability of nanofluids is crucial for their EOR applications. The stability of nanofluid is strongly influenced by the nature and properties of the disperse particle and the base fluid variables, including particle morphology, particles chemical structure and type of the base fluid. Accordingly, the main challenges of nanofluid stability are aggregation and sedimentation, which are not desirable to be present during the nanofluid flooding.

Many experiments utilising in situ contact angle measurements have been carried out based on laboratory experiment results (Grayling et al. 2018; Khishvand et al. 2016; Scanziani et al. 2017; Tudek et al. 2017) which demonstrated that in situ contact angle measurements are considered valid and accurate methodologies in terms of wettability alteration study and are significant in EOR applications (Klise et al. 2016). Therefore, obtaining high-resolution images with natural interpretation in a short time remains a challenge in the application of in situ contact angle measurements for nanofluid injection, while simultaneously developing ever more sophisticated techniques and logarithms used in measurement is profoundly challenging.

Among the EOR techniques currently employed, the nanofluids application is an advanced study and promising in the field of EOR optimisation methods. Though there are many research opportunities, there are relatively few available data on NP applications (compared with other techniques), and existing methodologies need to be developed and improved. Below are reviewed some of the most critical research opportunity areas related to the field of wettability alteration by using nanofluids.

- The effects of composite nanofluids (hybrids) on wettability alteration.

- The stability of nanofluids under different conditions (temperature, pressure, salinity, surface roughness).

- The effect of different types of NPs on wettability alteration using different rock systems.

- Improving the quality and resolution of in situ contact angle measurements, and developing algorithms used in automated methods of calculating contact angles.

- The effects of surface roughness on in situ contact angle measurements as a result of nanofluid flooding.

\section{Conclusion and summary}

This work provides a comprehensive review and analysis on the approach of wettability alteration by using nanofluid in porous media. This work provides a summary of theoretical and experimental works to extend the usage of nanofluid, focusing on wettability alteration of reservoir rocks and improving the oil recovery. The major conclusions are listed as follows:

- Nanoparticles can enhance oil recovery by improving fluids-rock interaction properties such as wettability alteration.

- The increase in nanoparticle concentration leads to incremental oil recovery associated with permeability reduction. Therefore, the optimum and stable concentration of the nanoparticles must be optimised before injection to obtain the maximum oil recovery.

- The stability of nanofluids is one of the crucial challenges in nanoflooding methodologies. It is concluded that the stability of nanofluids depends on the $\mathrm{pH}, \mathrm{NP}$ sizes, NP type (hydrophilic, hydrophobic, and amphiphilic), dispersion fluid, and sonication time.

- The nanoparticles are active on wettability alteration due to their ability to adsorption on or interact with the surface of the rock and altering the wettability from oil wet towards water wet. 


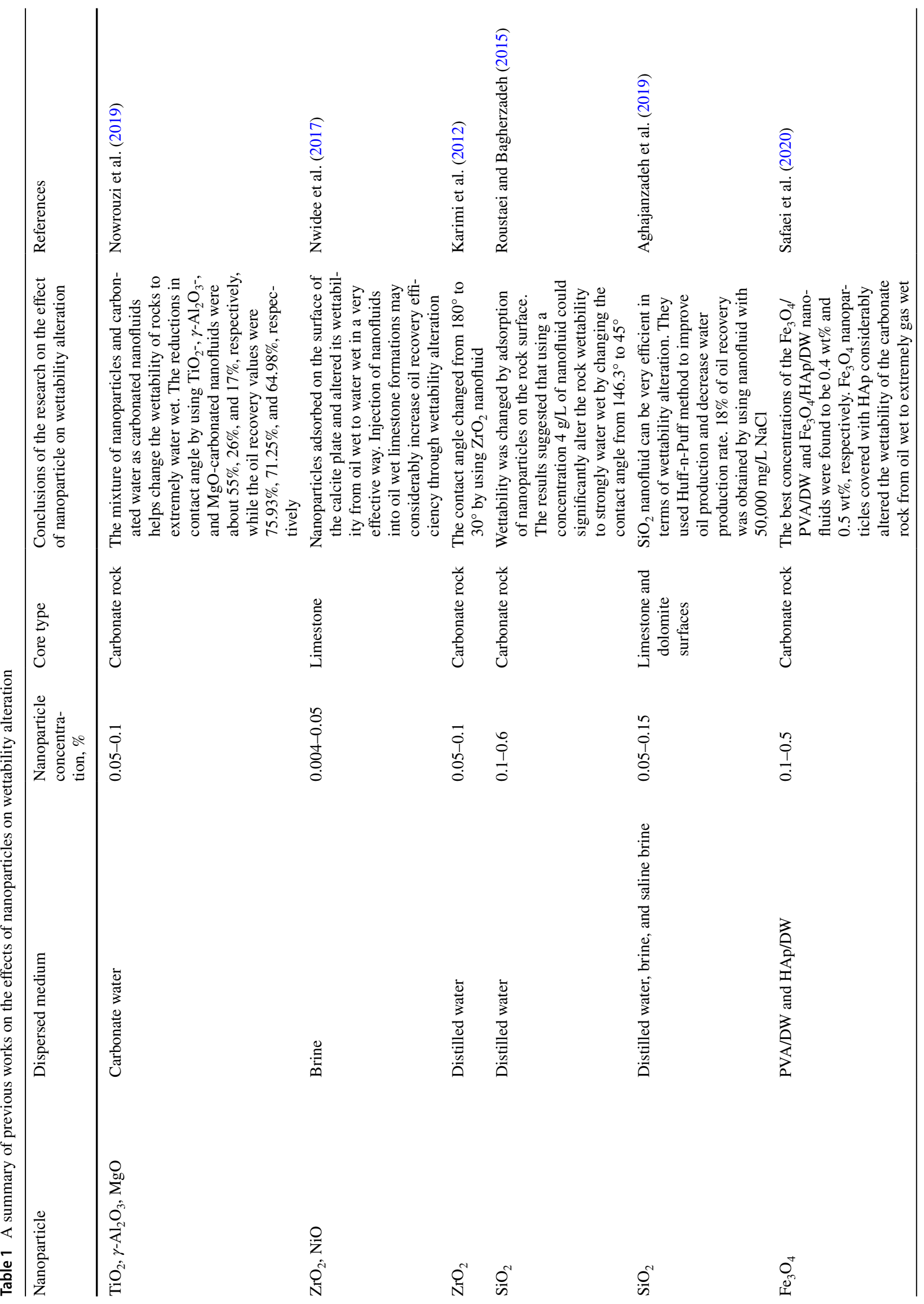




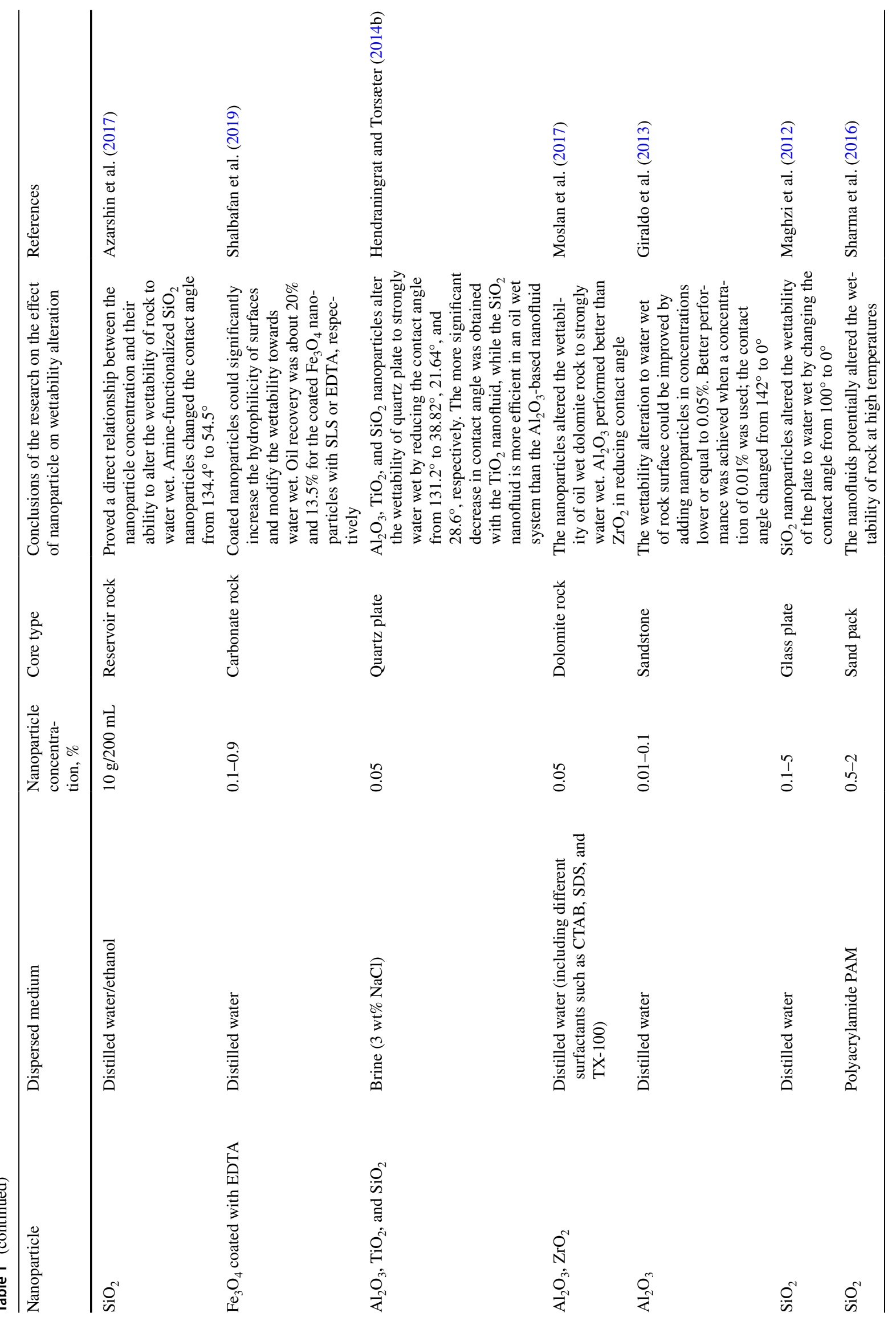




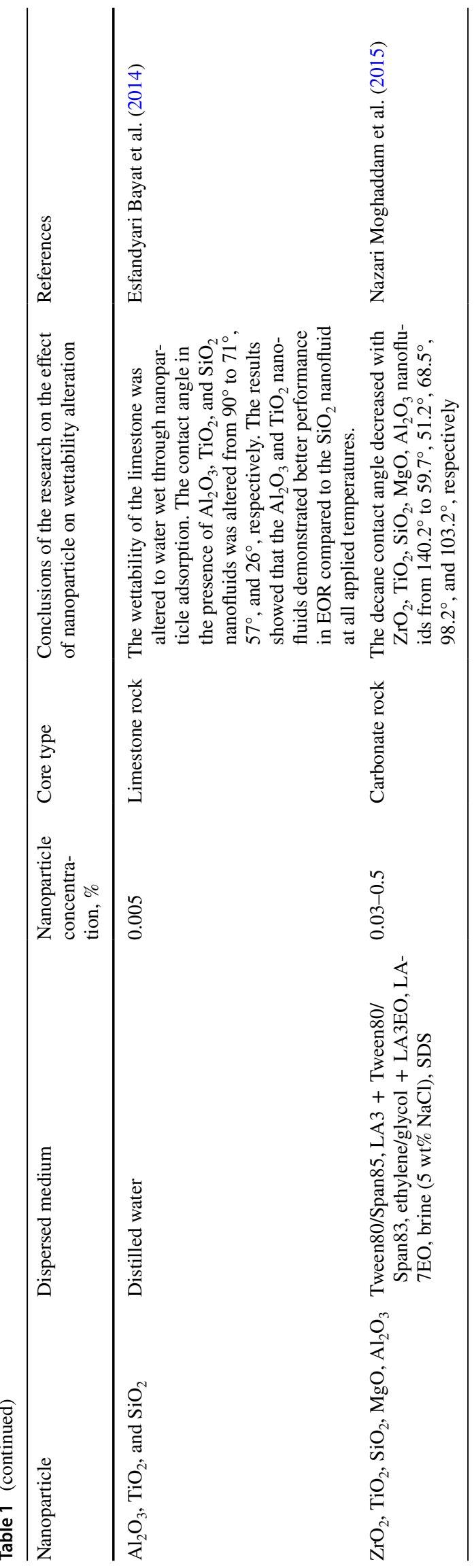

- Mixing nanoparticles with other chemical additives such as surfactant and polymer results in increasing their performance in wettability alteration of the wetting system.

Acknowledgements Financial supports from the National Natural Science Foundation of China (Grant No. U1762211, Grant No. 41702249, and Grant No. 51804316), the national major project (Grant No. 2017ZX05009), and the Science Foundation of China University of Petroleum, Beijing (Grant No. 2462017YJRC037) are greatly acknowledged.

Open Access This article is licensed under a Creative Commons Attribution 4.0 International License, which permits use, sharing, adaptation, distribution and reproduction in any medium or format, as long as you give appropriate credit to the original author(s) and the source, provide a link to the Creative Commons licence, and indicate if changes were made. The images or other third party material in this article are included in the article's Creative Commons licence, unless indicated otherwise in a credit line to the material. If material is not included in the article's Creative Commons licence and your intended use is not permitted by statutory regulation or exceeds the permitted use, you will need to obtain permission directly from the copyright holder. To view a copy of this licence, visit http://creativecommons.org/licenses/by/4.0/.

\section{References}

Adil M, Zaid HM, Chuan LK, Latiff NRA. Effect of dispersion stability on electrorheology of water-based $\mathrm{ZnO}$ nanofluids. Energy Fuels. 2016;30:6169-77. https://doi.org/10.1021/acs. energyfuels.6b01116.

Aghajanzadeh MR, Ahmadi P, Sharifi M, Riazi M. Wettability modification of oil-wet carbonate reservoirs using silica-based nanofluid: an experimental approach. J Pet Sci Eng. 2019;178:70010. https://doi.org/10.1016/j.petrol.2019.03.059.

Agi A, Junin R, Gbadamosi A. Mechanism governing nanoparticle flow behaviour in porous media: insight for enhanced oil recovery applications. Int Nano Lett. 2018;8:49-77. https://doi. org/10.1007/s40089-018-0237-3.

Ahmadi R, Farmani Z, Osfouri S, Azin R. Condensate blockage remediation in a gas reservoir through wettability alteration using natural $\mathrm{CaCO}_{3}$ nanoparticles. Colloids Surf A Physicochem Eng Aspects. 2019;579:123702. https://doi. org/10.1016/j.colsurfa.2019.123702.

Aksu I, Bazilevskaya E, Karpyn ZT. Swelling of clay minerals in unconsolidated porous media and its impact on permeability. Geo Res J. 2015;7:1-13. https://doi.org/10.1016/j. grj.2015.02.003.

Al-Anssari S, Barifcani A, Wang S, Maxim L, Iglauer S. Wettability alteration of oil-wet carbonate by silica nanofluid. J Colloid Interface Sci. 2016;461:435-42. https://doi.org/10.1016/j. jcis.2015.09.051.

Al-Anssari S, Wang S, Barifcani A, Lebedev M, Iglauer S. Effect of temperature and $\mathrm{SiO}_{2}$ nanoparticle size on wettability alteration of oil-wet calcite. Fuel. 2017;206:34-42. https://doi. org/10.1016/j.fuel.2017.05.077.

Alhammadi AM, AlRatrout A, Bijeljic B, Blunt MJ. In situ wettability measurement in a carbonate reservoir rock at high temperature and pressure. In: Abu Dhabi international petroleum exhibition and conference. Society of Petroleum Engineers, Abu Dhabi. 2017. https://doi.org/10.2118/188510-MS. 
Al-Hashim H, Kasha A, Abdallah W, Sauerer B. Impact of modified seawater on zeta potential and morphology of calcite and dolomite aged with stearic acid. Energy Fuels. 2018;32:1644-56. https://doi.org/10.1021/acs.energyfuels.7b03753.

Almahfood M, Bai B. The synergistic effects of nanoparticle-surfactant nanofluids in EOR applications. J Pet Sci Eng. 2018;171:196210. https://doi.org/10.1016/j.petrol.2018.07.030.

Alshakhs MJ, Kovscek AR. Understanding the role of brine ionic composition on oil recovery by assessment of wettability from colloidal forces. Adv Colloid Interface Sci. 2016;233:126-38. https://doi.org/10.1016/j.cis.2015.08.004.

Aminian A, ZareNezhad B. Wettability alteration in carbonate and sandstone rocks due to low salinity surfactant flooding. J Mol Liq. 2019;275:265-80. https://doi.org/10.1016/j.molli q.2018.11.080

Asadi A. An experimental investigation on the effects of ultrasonication time on stability and thermal conductivity of MWCNT-water nanofluid: finding the optimum ultrasonication time. Ultrason Sonochem. 2019;58:104639. https://doi. org/10.1016/j.ultsonch.2019.104639.

Azarshin S, Moghadasi J, Aboosadi Z. Surface functionalization of silica nanoparticles to improve the performance of water flooding in oil wet reservoirs. Energy Explor Exploit. 2017;35:68597. https://doi.org/10.1177/0144598717716281.

Baratpour M, Karimipour A, Afrand M, Wongwises S. Effects of temperature and concentration on the viscosity of nanofluids made of single-wall carbon nanotubes in ethylene glycol. Int Commun Heat Mass Transf. 2016;74:108-13. https://doi. org/10.1016/j.icheatmasstransfer.2016.02.008.

Bayat AE, Junin R. Transportation of metal oxide nanoparticles through various porous media for enhanced oil recovery. In: SPE/IATMI Asia Pacific oil and gas conference and exhibition. Society of Petroleum Engineers, Nusa Dua, Bali, Indonesia. 2015. https://doi.org/10.2118/176365-MS.

Belhaj AF, Elraies KA, Mahmood SM, Zulkifli NN, Akbari S, Hussien OS. The effect of surfactant concentration, salinity, temperature, and $\mathrm{pH}$ on surfactant adsorption for chemical enhanced oil recovery: a review. J Pet Explor Prod Technol. 2019. https://doi.org/10.1007/s13202-019-0685-y.

Bera A, Mandal A, Kumar T. The effect of rock-crude-oil-fluid interaction on wettability alteration of oil-wet sandstone in the presence of surfactants. Pet Sci Technol. 2015;33(5):542-9. https://doi.org/10.1080/10916466.2014.998768.

Betancur S, Carmona JC, Nassar NN, Franco CA, Cortés FB. Role of particle size and surface acidity of silica gel nanoparticles in inhibition of formation damage by asphaltene in oil reservoirs. Ind Eng Chem Res. 2016;55:6122-32. https://doi.org/10.1021/ acs.iecr.6b01187.

Bhuiyan MHU, Saidur R, Amalina MA, Mostafizur RM, Islam A. Effect of nanoparticles concentration and their sizes on surface tension of nanofluids. Proc Eng. 2015;105:431-7. https://doi. org/10.1016/j.proeng.2015.05.030.

Binks BP, Tyowua AT. Oil-in-oil emulsions stabilised solely by solid particles. Soft Matter. 2016;12:876-87. https://doi. org/10.1039/C5SM02438B.

Bolandtaba SF, Skauge A. Network modeling of EOR processes: a combined invasion percolation and dynamic model for mobilization of trapped oil. Transp Porous Med. 2011;89:357-82. https://doi.org/10.1007/s11242-011-9775-0.

Buonomo B, Manca O, Marinelli L, Nardini S. Effect of temperature and sonication time on nanofluid thermal conductivity measurements by nano-flash method. Appl Therm Eng. 2015;91:181-90. https://doi.org/10.1016/j.appltherma leng.2015.07.077.

Cardona L, Arias-Madrid D, Cortés F, Lopera S, Franco C. Heavy oil upgrading and enhanced recovery in a steam injection process assisted by $\mathrm{NiO}$ - and $\mathrm{PdO}$-functionalized $\mathrm{SiO}_{2}$ nanoparticulated catalysts. Catalysts. 2018;8:132. https://doi.org/10.3390/catal 8040132.

Cheraghian G. An experimental study of surfactant polymer for enhanced heavy oil recovery using a glass micromodel by adding nanoclay. Pet Sci Technol. 2015;33:1410-7. https://doi. org/10.1080/10916466.2015.1062780.

Cheraghian G. Effects of titanium dioxide nanoparticles on the efficiency of surfactant flooding of heavy oil in a glass micromodel. Pet Sci Technol. 2016;34(3):260-7. https://doi. org/10.1080/10916466.2015.1132233.

Cheraghian G. Evaluation of clay and fumed silica nanoparticles on adsorption of surfactant polymer during enhanced oil recovery. $\mathrm{J}$ Jpn Pet Inst. 2017a;60:85-94. https://doi.org/10.1627/jpi.60.85.

Cheraghian G. Synthesis and properties of polyacrylamide by nanoparticles, effect nanoclay on stability polyacrylamide solution. Micro Nano Lett. 2017b;12:40-4. https://doi.org/10.1049/ mnl.2016.0419.

Cheraghian G, Hendraningrat L. A review on applications of nanotechnology in the enhanced oil recovery part B: effects of nanoparticles on flooding. Int Nano Lett. 2016a;6:1-10. https://doi. org/10.1007/s40089-015-0170-7.

Cheraghian G, Hendraningrat L. A review on applications of nanotechnology in the enhanced oil recovery part A: effects of nanoparticles on interfacial tension. Int Nano Lett. 2016b;6:129-38. https ://doi.org/10.1007/s40089-015-0173-4.

Choi TJ, Jang SP, Kedzierski MA. Effect of surfactants on the stability and solar thermal absorption characteristics of water-based nanofluids with multi-walled carbon nanotubes. Int J Heat Mass Transf. 2018;122:483-90. https://doi.org/10.1016/j.ijheatmass transfer.2018.01.141.

Choon Pak B, Cho Y. Hydrodynamic and heat transfer study of dispersed fluids with submicron metallic oxide particle. Exp Heat Transf. 1998;11(2):151-70. https://doi.org/10.1080/0891615980 8946559.

Choudhary R, Khurana D, Kumar A, Subudhi S. Stability analysis of $\mathrm{Al}_{2} \mathrm{O}_{3}$ /water nanofluids. J Exp Nanosci. 2017;12:140-51. https ://doi.org/10.1080/17458080.2017.1285445.

Choudhary S, Sachdeva A, Kumar P. Investigation of the stability of $\mathrm{MgO}$ nanofluid and its effect on the thermal performance of flat plate solar collector. Renew Energy. 2019;147:1801-14. https:// doi.org/10.1016/j.renene.2019.09.126.

Chung SJ, Leonard JP, Nettleship I, Lee JK, Soong Y, Martello $\mathrm{DV}$, et al. Characterization of $\mathrm{ZnO}$ nanoparticle suspension in water: effectiveness of ultrasonic dispersion. Powder Technol. 2009;194(1-2):75-86. https://doi.org/10.1016/j.powte c. 2009.03.025.

Costa CAR, Leite CAP, Galembeck F. ESI-TEM Imaging of surfactants and ions sorbed in Stöber silica nanoparticles. Langmuir. 2006;22:7159-66. https://doi.org/10.1021/la060389p.

Dehaghani AHS, Daneshfar R. How much would silica nanoparticles enhance the performance of low-salinity water flooding. Pet Sci. 2019;16(3):591-605. https://doi.org/10.1007/s1218 2-019-0304-z.

Dehghan Monfared A, Ghazanfari MH, Jamialahmadi M, Helalizadeh A. The potential application of silica nanoparticles for wettability alteration of oil-wet calcite: a mechanistic study. Energy Fuels. 2016;30(5):3947-61. https://doi.org/10.1021/acs.energ yfuels.6b00477.

Devendiran DK, Amirtham VA. A review on preparation, characterization, properties and applications of nanofluids. Renew Sustain Energy Rev. 2016;60:21-40. https://doi.org/10.1016/j. rser.2016.01.055.

Druetta P, Picchioni F. Polymer and nanoparticles flooding as a new method for enhanced oil recovery. J Pet Sci Eng. 2019;177:47995. https://doi.org/10.1016/j.petrol.2019.02.070. 
Ehtesabi H, Ahadian MM, Taghikhani V, Ghazanfari MH. Enhanced heavy oil recovery in sandstone cores using $\mathrm{TiO}_{2}$ nanofluids. Energy Fuels. 2017;28:423-30. https://doi.org/10.1021/ef401 $338 \mathrm{c}$.

El-Diasty AI, Ragab AMS. Applications of nanotechnology in the oil and gas industry: latest trends worldwide and future challenges in Egypt. In: North Africa technical conference and exhibition. Society of Petroleum Engineers, Cairo, Egypt. 2013. https://doi. org/10.2118/164716-MS.

Esfandyari Bayat A, Junin R, Samsuri A, Piroozian A, Hokmabadi M. Impact of metal oxide nanoparticles on enhanced oil recovery from limestone media at several temperatures. Energy Fuels. 2014;28:6255-66. https://doi.org/10.1021/ef5013616.

Franco CA, Zabala R, Cortés FB. Nanotechnology applied to the enhancement of oil and gas productivity and recovery of Colombian fields. J Pet Sci Eng. 2017;157:39-55. https://doi. org/10.1016/j.petrol.2017.07.004.

Franco-Aguirre M, Zabala RD, Lopera SH, Franco CA, Cortés FB. Interaction of anionic surfactant-nanoparticles for gas-wettability alteration of sandstone in tight gas-condensate reservoirs. J Nat Gas Sci Eng. 2018;51:53-64. https://doi.org/10.1016/j.jngse .2017.12.027.

Gandomkar A, Rahimpour MR. The impact of monovalent and divalent ions on wettability alteration in oil/low salinity brine/limestone systems. J Mol Liq. 2017;248:1003-13. https://doi.org/10.1016/j. molliq.2017.10.095.

Gbadamosi AO, Junin R, Manan MA, Agi A, Oseh JO, Usman J. Effect of aluminium oxide nanoparticles on oilfield polyacrylamide: rheology, interfacial tension, wettability and oil displacement studies. J Mol Liq. 2019;296:111863. https://doi. org/10.1016/j.molliq.2019.111863.

Ghadimi A, Metselaar IH. The influence of surfactant and ultrasonic processing on improvement of stability, thermal conductivity and viscosity of titania nanofluid. Exp Therm Fluid Sci. 2013;51:1-9. https://doi.org/10.1016/j.expthermfl usci.2013.06.001.

Giraldo J, Benjumea P, Lopera S, Cortes FB, Ruiz MA. Wettability alteration of sandstone cores by alumina-based nanofluids. Energy Fuels. 2013;27(7):3659-65. https://doi.org/10.1021/ ef4002956.

Giraldo LJ, Giraldo MA, Llanos S, Maya G, Zabala RD, Nassar NN, et al. The effects of $\mathrm{SiO}_{2}$ nanoparticles on the thermal stability and rheological behavior of hydrolyzed polyacrylamide based polymeric solutions. J Pet Sci Eng. 2017;159:841-52. https:// doi.org/10.1016/j.petrol.2017.10.009.

Gomaa S, El-Hoshoudy A, Taha M. Investigating the effect of different nanoparticles on the interfacial tension reduction. Pet Petrochem Eng J. 2018;2:175. https://doi.org/10.23880/ppej-16000176.

Graves JE, Latvyte E, Greenwood A, Emekwuru NG. Ultrasonic preparation, stability and thermal conductivity of a capped coppermethanol nanofluid. Ultrason Sonochem. 2019;55:25-31. https ://doi.org/10.1016/j.ultsonch.2019.02.028.

Grayling KM, Young SD, Roberts CJ, de Heer MI, Shirley IM, Sturrock $\mathrm{CJ}$, et al. The application of X-ray micro computed tomography imaging for tracing particle movement in soil. Geoderma. 2018;321:8-14. https://doi.org/10.1016/j.geoderma.2018.01.038.

Gupta R, Mohanty KK. Temperature effects on surfactant-aided imbibition into fractured carbonates. SPE J. 2010;15:588-97. https:// doi.org/10.2118/110204-PA.

Hamouda AA, Rezaei Gomari KA. Influence of temperature on wettability alteration of carbonate reservoirs. In: SPE/DOE symposium on improved oil recovery. Society of Petroleum Engineers. 2006. https://doi.org/10.2118/99848-MS.

He Y, Jin Y, Chen H, Ding Y, Cang D, Lu H. Heat transfer and flow behaviour of aqueous suspensions of $\mathrm{TiO}_{2}$ nanoparticles (nanofluids) flowing upward through a vertical pipe. Int J Heat Mass
Transf. 2007;50(11-12):2272-81. https://doi.org/10.1016/j.ijhea tmasstransfer.2006.10.024

Hendraningrat L, Torsæter $\mathrm{O}$. Unlocking the potential of metal oxides nanoparticles to enhance the oil recovery. In: Offshore technology conference-Asia, 25-28 March, Kuala Lumpur, Malaysia. 2014a. https://doi.org/10.4043/24696-MS.

Hendraningrat L, Torsæter O. Metal oxide-based nanoparticles: revealing their potential to enhance oil recovery in different wettability systems. Appl Nanosci. 2014;5:181-99. https://doi.org/10.1007/ s13204-014-0305-6.

Hendraningrat L, Li S, Torsæter O. A coreflood investigation of nanofluid enhanced oil recovery. J Pet Sci Eng. 2013;111:128-38. https://doi.org/10.1016/j.petrol.2013.07.003.

Hogeweg AS, Hincapie RE, Foedisch H, Ganzer L. Evaluation of aluminium oxide and titanium dioxide nanoparticles for EOR applications. In: SPE Europec featured at 80th EAGE conference and exhibition. Society of Petroleum Engineers, Copenhagen, Denmark. 2018. https://doi.org/10.2118/190872-MS.

Hojjat M, Gholamreza Etemad S, Bagheri R, Thibault J. Rheological characteristics of non-Newtonian nanofluids: experimental investigation. Int Commun Heat Mass Transf. 2011;38(2):144-8. https ://doi.org/10.1016/j.icheatmasstransfer.2010.11.019.

Hou B, Jia R, Fu M, Wang Y, Jiang C, Yang B, et al. Wettability alteration of oil-wet carbonate surface induced by self-dispersing silica nanoparticles: mechanism and monovalent metal ion's effect. J Mol Liq. 2019;294:111601. https://doi.org/10.1016/j.molli q.2019.111601.

Huminic A, Huminic G, Fleaca C, Dumitrache F, Morjan I. Thermal conductivity, viscosity and surface tension of nanofluids based on FeC nanoparticles. Powder Technol. 2015;284:78-84. https ://doi.org/10.1016/j.powtec.2015.06.040.

Jafari Daghlian Sofla S, James LA, Zhang Y. Insight into the stability of hydrophilic silica nanoparticles in seawater for enhanced oil recovery implications. Fuel. 2018;216:559-71. https://doi. org/10.1016/j.fuel.2017.11.091.

Jang H, Lee W, Lee J. Nanoparticle dispersion with surface-modified silica nanoparticles and its effect on the wettability alteration of carbonate rocks. Colloids Surf A Physicochem Eng Aspects. 2018;554:261-71. https://doi.org/10.1016/j.colsu rfa.2018.06.045.

Jha NK, Ali M, Iglauer S, Lebedev M, Roshan H, Barifcani A, et al. Wettability alteration of quartz surface by low-salinity surfactant nanofluids at high-pressure and high-temperature conditions. Energy Fuels. 2019;33:7062-8. https://doi.org/10.1021/acs.energ yfuels.9b01102.

Jiang R, Li K, Horne R. A mechanism study of wettability and interfacial tension for EOR using silica nanoparticles. In: SPE annual technical conference and exhibition. Society of Petroleum Engineers, San Antonio, TX, USA. 2017. https://doi. org/10.2118/187096-MS.

Karimi A, Fakhroueian Z, Bahramian A, Pour Khiabani N, Darabad $\mathrm{JB}$, Azin R, et al. Wettability alteration in carbonates using zirconium oxide nanofluids: EOR implications. Energy Fuels. 2012;26:1028-36. https://doi.org/10.1021/ef201475u.

Kazemzadeh Y, Sharifi M, Riazi M, Rezvani H, Tabaei M. Potential effects of metal oxide/ $\mathrm{SiO}_{2}$ nanocomposites in EOR processes at different pressures. Colloids Surf A Physicochem Eng Aspects. 2018;559:372-84. https://doi.org/10.1016/j.colsu rfa.2018.09.068.

Kazemzadeh Y, Shojaei S, Riazi M, Sharifi M. Review on application of nanoparticles for EOR purposes: a critical review of the opportunities and challenges. Chin J Chem Eng. 2019;27(2):23746. https://doi.org/10.1016/j.cjche.2018.05.022.

Khishvand M, Alizadeh AH, Piri M. In-situ characterization of wettability and pore-scale displacements during twoand three-phase flow in natural porous media. Adv Water 
Resour. 2016;97:279-98. https://doi.org/10.1016/j.advwa tres.2016.10.009.

Klise KA, Moriarty D, Yoon H, Karpyn Z. Automated contact angle estimation for three-dimensional X-ray microtomography data. Adv Water Resour. 2016;95:152-60. https://doi.org/10.1016/j. advwatres.2015.11.006.

Kopanichuk IV, Vanin AA, Brodskaya EN. Disjoining pressure and structure of a fluid confined between nanoscale surfaces. Colloids Surf A Physicochem Eng Aspects. 2017;527:42-8. https://doi. org/10.1016/j.colsurfa.2017.04.072.

Kulak A, Hall SR, Mann S. Single-step fabrication of drug-encapsulated inorganic microspheres with complex form by sonicationinduced nanoparticle assembly. Chem Commun. 2004;5:576-7. https://doi.org/10.1039/b314465h.

Kwek D, Crivoi A, Duan F. Effects of temperature and particle size on the thermal property measurements of $\mathrm{Al}_{2} \mathrm{O}_{3}$ - water nanofluids. J Chem Eng Data. 2010;55:5690-5. https://doi.org/10.1021/ je1006407.

Lashkarbolooki M, Riazi M, Ayatollahi S, Zeinolabedini HA. Synergy effects of ions, resin, and asphaltene on interfacial tension of acidic crude oil and low-high salinity brines. Fuel. 2016;165:7585. https://doi.org/10.1016/j.fuel.2015.10.030.

Lee JH, Hwang KS, Jang SP, Lee BH, Kim JH, Choi SUS, et al. Effective viscosities and thermal conductivities of aqueous nanofluids containing low volume concentrations of $\mathrm{Al}_{2} \mathrm{O}_{3}$ nanoparticles. Int J Heat Mass Transf. 2008;51:2651-6. https://doi.org/10.1016/j. ijheatmasstransfer.2007.10.026.

Li F, Li L, Zhong G, Zhai Y, Li Z. Effects of ultrasonic time, size of aggregates and temperature on the stability and viscosity of $\mathrm{Cu}$-ethylene glycol (EG) nanofluids. Int J Heat Mass Transf. 2019;129:278-86. https://doi.org/10.1016/j.ijheatmasstrans fer.2018.09.104.

Li R, Jiang P, Gao C, Huang F, Xu R, Chen X. Experimental investigation of silica-based nanofluid enhanced oil recovery: the effect of wettability alteration. Energy Fuels. 2017;31:188-97. https:// doi.org/10.1021/acs.energyfuels.6b02001.

Li X, Zhu D, Wang X. Experimental investigation on viscosity of $\mathrm{Cu}-\mathrm{H}_{2} \mathrm{O}$ nanofluids. J Wuhan Univ Technol Mater Sci Ed. 2009;24:48-52.

Lim S, Horiuchi H, Nikolov AD, Wasan D. Nanofluids alter the surface wettability of solids. Langmuir. 2015;31:5827-35. https://doi. org/10.1021/acs.langmuir.5b00799.

Lim S, Wasan D. Structural disjoining pressure induced solid particle removal from solid substrates using nanofluids. J Colloid Interface Sci. 2017;500:96-104. https://doi.org/10.1016/j. jcis.2017.03.108.

Llanos S, Giraldo LJ, Santamaria O, Franco CA, Cortés FB. Effect of sodium oleate surfactant concentration grafted onto $\mathrm{SiO}_{2}$ nanoparticles in polymer flooding processes. ACS Omega. 2018;3:18673-84. https://doi.org/10.1021/acsomega.8b02944.

Luo D, Wang F, Zhu J, Cao F, Liu Y, Li X, et al. Nanofluid of graphenebased amphiphilic Janus nanosheets for tertiary or enhanced oil recovery: high performance at low concentration. Proc Natl Acad Sci USA. 2016;113:7711-6. https://doi.org/10.1073/pnas.16081 35113.

Maghzi A, Mohammadi S, Ghazanfari MH, Kharrat R, Masihi M. Monitoring wettability alteration by silica nanoparticles during water flooding to heavy oils in five-spot systems: a pore-level investigation. Exp Therm Fluid Sci. 2012;40:168-76. https://doi. org/10.1016/j.expthermflusci.2012.03.004

Mahani H, Keya AL, Berg S, Nasralla R. The effect of salinity, rock type and ph on the electrokinetics of carbonate-brine interface and surface complexation modeling. In: SPE reservoir characterisation and simulation conference and exhibition. Society of Petroleum Engineers, Abu Dhabi, UAE. 2015. https://doi. org/10.2118/175568-MS.
Mahbubul IM, Shahrul IM, Khaleduzzaman SS, Saidur R, Amalina MA, Turgut A. Experimental investigation on effect of ultrasonication duration on colloidal dispersion and thermophysical properties of alumina-water nanofluid. Int J Heat Mass Transf. 2015;88:73-81. https://doi.org/10.1016/j.ijheatmasstrans fer.2015.04.048.

Mahbubul IM. 2-Preparation of nanofluid. In: Mahbubul IM, editor. Preparation, characterization, properties and application of nanofluid. Norwich: William Andrew Publishing; 2019a. p. 15-45. https://doi.org/10.1016/B978-0-12-813245-6.00002-2.

Mahbubul IM. 5-Rheological behavior of nanofluid. In: Mahbubul IM, editor. Preparation, characterization, properties and application of nanofluid. Norwich: William Andrew Publishing; 2019b. p. 197-229. https://doi.org/10.1016/B978-0-12-813245-6.00005-8.

Mahmoud O, Nasr-El-Din HA, Vryzas Z, Kelessidis VC. Nanoparticlebased drilling fluids for minimizing formation damage in HP/ HT applications. In: SPE international conference and exhibition on formation damage control. Society of Petroleum Engineers, Lafayette, Louisiana, USA. 2016. https://doi.org/10.2118/17894 9-MS.

Manoudis PN, Karapanagiotis I. Modification of the wettability of polymer surfaces using nanoparticles. Prog Org Coat. 2014;77:3318. https://doi.org/10.1016/j.porgcoat.2013.10.007.

Mansouri M, Nakhaee A, Pourafshary P. Effect of $\mathrm{SiO}_{2}$ nanoparticles on fines stabilization during low salinity water flooding in sandstones. J Pet Sci Eng. 2019;174:637-48. https://doi. org/10.1016/j.petrol.2018.11.066.

Manzari Tavakoli H, Jamialahmadi M, Kord S, Daryasafar A. Experimental investigation of the effect of silica nanoparticles on the kinetics of barium sulfate scaling during water injection process. J Pet Sci Eng. 2018;169:344-52. https://doi. org/10.1016/j.petrol.2018.05.077.

Masoud Hosseini S, Vafajoo L, Ghasemi E, Salman BH. Experimental investigation the effect of nanoparticle concentration on the rheological behavior of paraffin-based nickel ferrofluid. Int J Heat Mass Transf. 2016;93:228-34. https://doi.org/10.1016/j. ijheatmasstransfer.2015.09.082.

Mohammad Salehi M, Omidvar P, Naeimi F. Salinity of injection water and its impact on oil recovery absolute permeability, residual oil saturation, interfacial tension and capillary pressure. Egypt J Pet. 2017;26:301-12. https://doi.org/10.1016/j. ejpe.2016.05.003.

Moncayo-Riascos I, Cortés FB, Hoyos BA. Chemical alteration of wettability of sandstones with polysorbate 80 : experimental and molecular dynamics study. Energy Fuels. 2017;31:11918-24. https://doi.org/10.1021/acs.energyfuels.7b02263.

Moncayo-Riascos I, Franco CA, Cortés FB. Dynamic molecular modeling and experimental approach of fluorocarbon surfactantfunctionalized $\mathrm{SiO}_{2}$ nanoparticles for gas-wettability alteration on sandstones. J Chem Eng Data. 2019;64:1860-72. https://doi. org/10.1021/acs.jced.8b00910.

Moslan MS, Sulaiman WRW, Ismail AR, Jaafar MZ. Applications of aluminium oxide and zirconium oxide nanoparticles in altering dolomite rock wettability using different dispersing medium. Chem Eng Trans. 2017;56:1339-44. https://doi.org/10.3303/ CET1756224.

Nazari Moghaddam R, Bahramian A, Fakhroueian Z, Karimi A, Arya S. Comparative study of using nanoparticles for enhanced oil recovery: wettability alteration of carbonate rocks. Energy Fuels. 2015;29:2111-9. https://doi.org/10.1021/ef5024719.

Nguyen CT, Desgranges F, Roy G, Galanis N, Mare T, Boucher S, et al. Temperature and particle-size dependent viscosity data for water-based nanofluids-hysteresis phenomenon. Int J Heat Fluid Flow. 2007;28(6):1492-506. https://doi.org/10.1016/j.ijhea tfluidflow.2007.02.004. 
Nicolini JV, Ferraz HC, Borges CP. Effect of seawater ionic composition modified by nanofiltration on enhanced oil recovery in Berea sandstone. Fuel. 2017;203:222-32. https://doi.org/10.1016/j. fuel.2017.04.120.

Nowrouzi I, Khaksar Manshad AH, Mohammadi A. Effects of $\mathrm{TiO}_{2}$, $\mathrm{MgO}$, and $\gamma-\mathrm{Al}_{2} \mathrm{O}_{3}$ nano-particles in carbonated water on wateroil interfacial tension (IFT) reduction in chemical enhanced oil recovery (CEOR) process. J Mol Liq. 2019. https://doi. org/10.1016/j.molliq.2019.111348.

Nwidee LN, Al-Anssari S, Barifcani A, Sarmadivaleh M, Lebedev M, Iglauer S. Nanoparticles influence on wetting behaviour of fractured limestone formation. J Pet Sci Eng. 2017;149:782-8. https://doi.org/10.1016/j.petrol.2016.11.017.

Ogolo NA, Olafuyi OA, Onyekonwu MO. Enhanced oil recovery using nanoparticles. In: SPE Saudi Arabia section technical symposium and exhibition. Society of Petroleum Engineers, Al-Khobar, Saudi Arabia. 2012. https://doi.org/10.2118/160847-MS.

Ogolo NA, Onyekonwu MO, Akaranta O. Trapping mechanism of nanofluids on migrating fines in sand. In: SPE Nigeria annual international conference and exhibition. Society of Petroleum Engineers, Lagos, Nigeria. 2013. https://doi.org/10.2118/16750 2-MS.

Ortega DJS, Kim HB, James LA, Johansen TE, Zhang Y. The effectiveness of silicon dioxide $\mathrm{SiO}_{2}$ nanoparticle as an enhanced oil recovery agent in Ben Nevis Formation, Hebron Field, Offshore Eastern Canada. In: Abu Dhabi international petroleum exhibition and conference. Society of Petroleum Engineers, Abu Dhabi, UAE. 2016. https://doi.org/10.2118/183546-MS.

Prasher R, Song D, Wang J, Phelan P. Measurements of nanofluid viscosity and its implications for thermal applications. Appl Phys Lett. 2006;89:133108. https://doi.org/10.1063/1.2356113.

Puntervold T. Waterflooding of carbonate reservoirs: EOR by wettability alteration. PhD Thesis. University of Stavanger, Norway. 2008.

Rahmani AR, Bryant S, Huh C, Athey A, Ahmadian M, Chen J, et al. Crosswell magnetic sensing of superparamagnetic nanoparticles for subsurface applications. SPE J. 2015;20:1067-82. https://doi. org/10.2118/166140-PA.

Raj I, Qu M, Xiao L, Hou J, Li Y, Liang T, et al. Ultralow concentration of molybdenum disulfide nanosheets for enhanced oil recovery. Fuel. 2019;251:514-22. https://doi.org/10.1016/j. fuel.2019.04.078.

RezaeiDoust A, Puntervold T, Strand S, Austad T. Smart water as wettability modifier in carbonate and sandstone: a discussion of similarities/differences in the chemical mechanisms. Energy Fuels. 2009;23:4479-85. https://doi.org/10.1021/ef900185q.

Rezk MY, Allam NK. Unveiling the synergistic effect of $\mathrm{ZnO}$ nanoparticles and surfactant colloids for enhanced oil recovery. Colloid Interface Sci Commun. 2019;29:33-9. https://doi.org/10.1016/j. colcom.2019.01.004.

Rivet S, Lake LW, Pope GA. A coreflood investigation of low-salinity enhanced oil recovery, In: SPE annual technical conference and exhibition. In: SPE annual technical conference and exhibition. Society of Petroleum Engineers, Florence, Italy. 2010. https:// doi.org/10.2118/134297-MS.

Roustaei A, Bagherzadeh $\mathrm{H}$. Experimental investigation of $\mathrm{SiO}_{2}$ nanoparticles on enhanced oil recovery of carbonate reservoirs. J Pet Explor Prod Technol. 2015;5:27-33. https://doi.org/10.1007/ s13202-014-0120-3.

Safaei A, Esmaeilzadeh F, Sardarian A, Mousavi SM, Wang X. Experimental investigation of wettability alteration of carbonate gascondensate reservoirs from oil-wetting to gas-wetting using $\mathrm{Fe}_{3} \mathrm{O}_{4}$ nanoparticles coated with poly(vinyl alcohol), (PVA) or hydroxyapatite (HAp). J Pet Sci Eng. 2020;184:106530. https:// doi.org/10.1016/j.petrol.2019.106530.
Samal S, Satpati B, Chaira D. Production and dispersion stability of ultrafine $\mathrm{Al}-\mathrm{Cu}$ alloy powder in base fluid. J Alloys Compd. 2010;504:S389-94. https://doi.org/10.1016/j.jallc om.2010.03.223.

Sameni A, Pourafshary P, Ghanbarzadeh M, Ayatollahi S. Effect of nanoparticles on clay swelling and migration. Egypt J Pet. 2015;24:429-37. https://doi.org/10.1016/j.ejpe.2015.10.006.

Scanziani A, Singh K, Blunt MJ, Guadagnini A. Automatic method for estimation of in situ effective contact angle from X-ray micro tomography images of two-phase flow in porous media. J Colloid Interface Sci. 2017;496:51-9. https://doi.org/10.1016/j. jcis.2017.02.005

Schmidt A, Chiesa M, Torchinsky D, Johnson J, Boustani A, Mckinley $\mathrm{G}$, et al. Experimental investigation of nanofluid shear and longitudinal viscosities. Appl Phys Lett. 2008;92(24):244107. https:// doi.org/10.1063/1.2945799.

Schramm LL. Surfactants: fundamentals and applications in the petroleum industry. Cambridge: Cambridge University Press; 2000.

Sezer N, Atieh MA, Koç M. A comprehensive review on synthesis, stability, thermophysical properties, and characterization of nanofluids. Powder Technol. 2019;344:404-31. https://doi. org/10.1016/j.powtec.2018.12.016.

Shalbafan M, Esmaeilzadeh F, Safaei A, Wang X. Experimental investigation of wettability alteration and oil recovery enhance in carbonate reservoirs using iron oxide nanoparticles coated with EDTA or SLS. J Pet Sci Eng. 2019;180:559-68. https:// doi.org/10.1016/j.petrol.2019.05.085.

Sharma T, Iglauer S, Sangwai JS. Silica nanofluids in an oilfield polymer polyacrylamide: interfacial properties, wettability alteration, and applications for chemical enhanced oil recovery. Ind Eng Chem Res. 2016;55:12387-97. https://doi.org/10.1021/acs. iecr.6b03299.

Shen G. Effect of ultrasonic waves on heat transfer in $\mathrm{Al}_{2} \mathrm{O}_{3}$ nanofluid under natural convection and pool boiling. Int $\mathrm{J}$ Heat Mass Transf. 2019;138:516-23. https://doi.org/10.1016/j.ijheatmass transfer.2019.04.071.

Sheng JJ. Critical review of low-salinity waterflooding. J Pet Sci Eng. 2014;120:216-24. https://doi.org/10.1016/j.petrol.2014.05.026.

Singh R, Mahto V. Synthesis, characterization and evaluation of polyacrylamide graft starch/clay nanocomposite hydrogel system for enhanced oil recovery. Pet Sci. 2017;14:765-79. https://doi. org/10.1007/s 12182-017-0185-y.

Sommers AD, Yerkes KL. Experimental investigation into the convective heat transfer and system-level effects of $\mathrm{Al}_{2} \mathrm{O}_{3}$-propanol nanofluid. J Nanopart Res. 2010;12(3):1003-14. https://doi. org/10.1007/s11051-009-9657-3.

Sun X, Zhang Y, Chen G, Gai Z. Application of nanoparticles in enhanced oil recovery: a critical review of recent progress. Energies. 2017;10:345. https://doi.org/10.3390/en10030345.

Taheri-Shakib J, Shekarifard A, Naderi H. Heavy crude oil upgrading using nanoparticles by applying electromagnetic technique. Fuel. 2018;232:704-11. https://doi.org/10.1016/j.fuel.2018.06.023.

Tarek M. Investigating nano-fluid mixture effects to enhance oil recovery. In: SPE annual technical conference and exhibition. Society of Petroleum Engineers, Houston, Texas, USA. 2015. https://doi. org/10.2118/178739-STU.

Tola S, Sasaki K, Sugai Y. Wettability alteration of sandstone with zinc oxide nano-particles. Society of Petrophysicists and Well-Log Analysts SPWLA-JFES-2017-E, 4. 2017. https://www.onepetro. org/conference-paper/SPWLA-JFES-2017-E.

Torsater O, Engeset B, Hendraningrat L, Suwarno S. Improved oil recovery by nanofluids flooding: an experimental study. In: SPE Kuwait international petroleum conference and exhibition. Society of Petroleum Engineers, Kuwait City, Kuwait. 2012. https:// doi.org/10.2118/163335-MS. 
Tudek J, Crandall D, Fuchs S, Werth CJ, Valocchi AJ, Chen Y, et al. In situ contact angle measurements of liquid $\mathrm{CO}_{2}$, brine, and Mount Simon sandstone core using micro X-ray CT imaging, sessile drop, and Lattice Boltzmann modeling. J Pet Sci Eng. 2017;155:3-10. https://doi.org/10.1016/j.petrol.2017.01.047.

Turgut A, Tavman I, Chirtoc M, Schuchmann HP, Sauter C, Tavman $\mathrm{S}$. Thermal conductivity and viscosity measurements of waterbased $\mathrm{TiO}_{2}$ nanofluids. Int J Thermophys. 2009;30:1213-26. https://doi.org/10.1007/s10765-009-0594-2.

Wang J, Cao X, Fang L, You X, Wong K, Cao S, et al. $\mathrm{MoS}_{2}$ nanoflower supported $\mathrm{Pt}$ nanoparticle as an efficient electrocatalyst for ethanol oxidation reaction. Int J Hydrog Energy. 2019;44:1641123. https://doi.org/10.1016/j.ijhydene.2019.04.251.

Wang L, Shi B, Chai Z. Effects of temperature-dependent properties on natural convection of nanofluids in a partially heated cubic enclosure. Appl Therm Eng. 2018;128:204-13. https://doi. org/10.1016/j.applthermaleng.2017.09.006.

Yin T, Yang Z, Dong Z, Lin M, Zhang J. Physicochemical properties and potential applications of silica-based amphiphilic Janus nanosheets for enhanced oil recovery. Fuel. 2019;237:344-51. https://doi.org/10.1016/j.fuel.2018.10.028.

Yousefvand HA, Jafari A. Stability and flooding analysis of nanosilica/ $\mathrm{NaCl} / \mathrm{HPAM}$ /SDS solution for enhanced heavy oil recovery. J Pet Sci Eng. 2018;162:283-91. https://doi.org/10.1016/j.petro 1.2017.09.078.

Yu F, Chen Y, Liang X, Xu J, Lee C, Liang Q, et al. Dispersion stability of thermal nanofluids. Progr Nat Sci Mater Int. 2017;27:531-42. https://doi.org/10.1016/j.pnsc.2017.08.010.

Yuan B, Wang W, Moghanloo RG, Su Y, Wang K, Jiang M. Permeability reduction of Berea cores owing to nanoparticle adsorption onto the pore surface: mechanistic modelling and experimental work. Energy Fuels. 2017;31:795-804. https://doi.org/10.1021/ acs.energyfuels.6b02108.

Yuan B, Moghanloo RG, Wang W. Using nanofluids to control fines migration for oil recovery: nanofluids co-injection or nanofluids pre-flush? A comprehensive answer. Fuel. 2018;215:474-83. https://doi.org/10.1016/j.fuel.2017.11.088.

Zabala R, Franco CA, Cortés FB. Application of nanofluids for improving oil mobility in heavy oil and extra-heavy oil: a field test. In: SPE improved oil recovery conference. Society of Petroleum Engineers, Tulsa, Oklahoma, USA. 2016. https://doi. org/10.2118/179677-MS.

Zaid HM, Radzi NSA, Latiff NRA, Shafie A. Effect of morphology of aluminium oxide nanoparticles on viscosity and interfacial tension (IFT) and the recovery efficiency in enhanced oil recovery (EOR). In: 3RD international conference on fundamental and applied sciences (ICFAS 2014): innovative research in applied sciences for a sustainable future, Kuala Lumpur, Malaysia, pp. 705-710. 2014. https://doi.org/10.1063/1.4898545.

Zawrah MF, Khattab RM, Girgis LG, El Daidamony H, Abdel Aziz RE. Stability and electrical conductivity of water-base $\mathrm{Al}_{2} \mathrm{O}_{3}$ nanofluids for different applications. HBRC J. 2016;12:227-34. https://doi.org/10.1016/j.hbrcj.2014.12.001.

Zekri A, Al-Attar H, Al-Farisi O, Almehaideb R, Lwisa E. Experimental investigation of the effect of injection water salinity on the displacement efficiency of miscible carbon dioxide WAG flooding in a selected carbonate reservoir. J Pet Explor Prod Technol. 2015;5(4):363-73. https://doi.org/10.1007/s13202-015-0155-0. 